Energy Systems Environmental Restoration Program ORNL Environmental Restoration Program

\title{
Guidance Document for the Preparation of Waste Management Plans for the Environmental Restoration Program at Oak Ridge National Laboratory
}

\author{
C. Clark, Jr.
}

Date Issued-July 1993

Prepared for

U.S. Department of Energy

Office of Environmental Restoration and Waste Management under budget and reporting code EW 20

OAK RIDGE NATIONAL LABORATORY

Oak Riỏge, Tennessee 37831-6285 managed by

MARTIN MARIETTA ENERGY SYSTEMS, INC. for the U.S. DEPARTMENT OF ENERGY under contract DE-AC05-84OR21400 


\section{Author Affiliation}

C. Clark, Jr., is a member of the Environmental Restoration Program of Oak Ridge National Laboratory Martin Marietta Energy Systems, Inc. 


\section{CONTENTS}

ABBREVIATIONS $\ldots \ldots \ldots \ldots \ldots \ldots \ldots \ldots \ldots \ldots \ldots \ldots \ldots \ldots \ldots \ldots$

EXECUTTVE SUMMARY $\ldots \ldots \ldots \ldots \ldots \ldots \ldots \ldots \ldots \ldots \ldots \ldots$ vii

INTRODUCTION AND OVERVIEW OF THE PREPARATION OF ORNL

ER PROGRAM WM PLANS AND CHECKLISTS $\ldots \ldots \ldots \ldots \ldots \ldots \ldots \ldots 1$

I. PURPOSE $\ldots \ldots \ldots \ldots \ldots \ldots \ldots \ldots \ldots \ldots \ldots \ldots \ldots \ldots \ldots \ldots \ldots$

II. BIBLIOGRAPHY $\ldots \ldots \ldots \ldots \ldots \ldots \ldots \ldots \ldots \ldots \ldots \ldots \ldots \ldots \ldots$

III. SCOPE AND LIMITATIONS $\ldots \ldots \ldots \ldots \ldots \ldots \ldots \ldots \ldots \ldots \ldots \ldots$

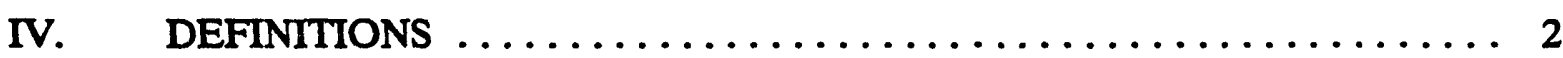

V. REQUIREMENTS $\ldots \ldots \ldots \ldots \ldots \ldots \ldots \ldots \ldots \ldots \ldots \ldots \ldots \ldots \ldots \ldots \ldots \ldots$

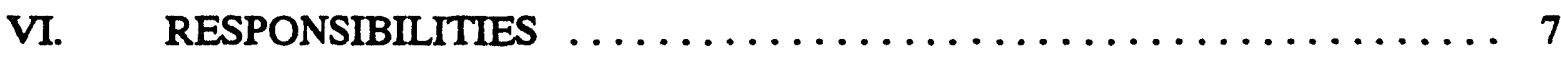

VII. REQUIRED RECORDS AND CHANGE CONTROL PROCEDURES .. 11

VIII. ADMINISTRATION $\ldots \ldots \ldots \ldots \ldots \ldots \ldots \ldots \ldots \ldots \ldots \ldots \ldots$

APPENDIX A: Outline for Project WM Plan $\ldots \ldots \ldots \ldots \ldots \ldots \ldots \ldots \ldots, 13$

APPENDIX B: ORNL ER Program WM Checklist and Instructions $\ldots \ldots \ldots \ldots 17$

APPENDIX C: ORNL/ER Program WM Forms and

Instructions for Completing Forms $\ldots \ldots \ldots \ldots \ldots \ldots \ldots, 37$

ATTACHMENT 1. UCN Form-2822, Request for Storage or

Disposal of Radioactive Solid Waste or

Special Materials $\ldots \ldots \ldots \ldots \ldots \ldots \ldots \ldots \ldots \ldots \ldots, 41$

ATTACHMENT 2. UCN Form-16114, Log-In Data

Sheet for Generators of Solid Low-Level Waste ........... 47

ATTACHMENT 3. UCN Tag-2785, Radiation

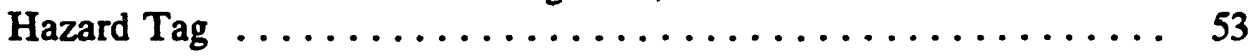

ATTACHMENT 4. UCN Tag-13075, General Low-Level

Radioactive Compactible Waste Tag ............... 57

ATTACHMENT 5. UCN Form-13698, Request for

Disposal of Hazardous and Mixed Waste .............. 61 
ATTACHMENT 6. UCN Form-13386, Request for the Disposal of Asbestos or Material

Containing Asbestos

ATTACHMENT 7. UCN Form-19611, Environmental Restoration Waste Management Program

Generated Waste Form Summary Report

ATTACHMENT 8. Environmental Restoration Program

Waste Generation Forecast

ATTACHMENT 9. TX-5352 Form, Log-In Data Sheets for Packaging TRU ......................

ATTACHMENT 10. TX-5352A Form, Log-In Data Sheets for Packaging TRU Mixed Waste

ATTACHMENT 11. UCN Form-2109, Request for Transfer, Storage, or Disposal of Waste $\ldots \ldots \ldots \ldots \ldots \ldots \ldots \ldots \ldots$

APPENDIX D: The Proposed Energy Systems Uniform Waste Request Sheets for Waste Transfer from Generators to Waste Operations 


\section{ABBREVIATIONS}

$\begin{array}{ll}\text { AEC } & \text { Atomic Energy Commission } \\ \text { AOC } & \text { area of contamination } \\ \text { CERCLA } & \text { Comprehensive Environmental Response, Compensation, and Liability Act } \\ \text { CPL } & \text { Container Packing List form } \\ \text { D\&D } & \text { decommission and decontamination } \\ \text { DOE } & \text { U.S. Department of Energy } \\ \text { DOT } & \text { U.S. Department of Transportation } \\ \text { Energy Systems } & \text { Martin Marietta Energy Systems, Inc. } \\ \text { EPA } & \text { U.S. Environmental Protection Agency } \\ \text { ER } & \text { Environmental Restoration } \\ \text { ES\&H } & \text { environmental, safety, and health } \\ \text { GCO } & \text { generator certification official } \\ \text { IDW } & \text { investigation-derived waste } \\ \text { LCO } & \text { laboratory certification official } \\ \text { ORNL } & \text { Oak Ridge National Laboratory } \\ \text { OSWER } & \text { Office of Solid Waste and Emergency Response } \\ \text { PM } & \text { project manager } \\ \text { PPE } & \text { personal protective equipment } \\ \text { QA } & \text { Quality Assurance } \\ \text { RCRA } & \text { Resource Conservation and Recivery Act } \\ \text { ROD } & \text { Record of Decision } \\ \text { RA } & \text { remedial action } \\ \text { RI } & \text { remedial investigation } \\ \text { SLLW } & \text { solid low-level waste } \\ \text { TRU } & \text { transuranic } \\ \text { WAGM } & \text { Waste Area Grouping Manager } \\ \text { WID } & \text { Waste Item Description form } \\ \text { WM } & \text { waste management } \\ \text { WMO } & \text { Waste Management Organization } \\ \text { WPR } & \text { Waste Pickup Request form } \\ \text { VLA } & \text { very low activity } \\ & \end{array}$




\section{EXECUTIVE SUMMARY}

A project waste management (WM) plan is required for all Oak Ridge National Laboratory (ORNL) Environmental Restoration (ER) Program remedial investigation, decommission and decontamination (D\&D), and remedial action (RA) activities. The project WM plan describes the strategy for handling, packaging, treating, transporting, characterizing, storing, and/or disposing of waste produced as part of ORNL ER Program activities. The project WM plan also contains a strategy for ensuring worker and environmental protection during $W M$ activities.

The strategy set forth in the WM plan incorporates the most appropriate combination of waste minimization, segregation, treatment, storage, and disposal practices. Such practices shall protect the environment and human health by keeping radiation and chemical exposure as low as reasonably achievable. The WM plan also includes the guidance provided by the Environmental Protection Agency (EPA) in Guide to Management of Investigation-Derived Wastes, Office of Solid Waste and Emergency Response (OSWER), Directive No. 9345.303FS (EPA 1992). For RAs, the strategy for WM activities within the area of contamination is to be consistent with EPA guidance.

Subprojects or tasks performed under the project WM plan (the umbrella document) may use the checklist provided in Appendix $\mathrm{C}$ as the official subproject or task WM plan and may reference the umbrella document for more specific details. The WM plan checklist shall contain specific details of how, who, and when WM activities will be performed.

Included as part of this guidance document are appendixes that give guidance and definitions pertaining to the preparation of the project WM plan and checklist. Appendix A is the "Outline for Project WM Plan (Project WM Umbrella Document)." Appendix B, "ORNL ER Program WM Checklist and Instructions," defines the specific responsibilities of those who perform specific tasks affiliated with waste generating and waste managing activities. Appendix C, "ORNL/ER Program WM Forms and Instructions for Completing the Forms," contains illustrations of the various forms for transferring waste to ORNL Waste Operations. Appendix D contains the proposed WM forms that will be initiated during fall 1993. 


\section{INTRODUCTION AND OVERVIEW OF THE PREPARATION OF ORNL ER PROGRAM WM PLANS AND CHECKLISTS}

\section{PURPOSE}

The purpose of this document and referenced policies and procedures is to define the activities associated with the preparation of Oak Ridge National Laboratory (ORNL) Environmental Restoration (ER) Program Waste Management (WM) plans. This document supports the Martin Marietta Energy Systems, Inc. (Energy Systems) ER WM policy of safely handling and storing waste materials generated by ER activities in compliance with applicable federal and state regulations, U.S. Department of Energy (DOE) orders, and Energy Systems policies. It implements the DOE ER Program WM Plan, DOE/ORO 976.

\section{BIBLIOGRAPHY}

\section{A. Source Documents}

Department of Transportation (DOT) Regulations, 49 CFR Parts 171 through 179.

DOE Field Office, Oak Ridge Environmental Restoration Program Waste Management Plan, DOE/ORO 976, Rev. 0, Martin Marietta Energy Systems, Inc. Oak Ridge, Tennessee, September 1991.

Environmental Restoration Program Waste Minimization And Pollution Prevention Awareness Program Plan, Martin Marietta Energy Systems, Inc., Oak Ridge, Tennessee, September 15, 1991.

Martin Marietta Energy Systems, Quality Procedures Manual, December 8, 1989.

Science Applications International Corporation, Environmental Restoration OR-1 Project Waste Management Implementation Plan, Oak Ridge, Tennessee.

U.S. Environmental Protection Agency (EPA) Regulations for Hazardous Waste Transporters, 40 CFR Part 263.

B. Other References

ORNL "Waste Acceptance Criteria for Radioactive Solid Waste Disposal at SWSA-6, WM-WMCO-203," April 1993.

Methodology for Generating Waste Volume Estimates, ES/ER/TM-18, Martin Marietta Energy Systems, Inc. Oak Ridge, Tennessee, September 1991.

ORNL Radioactive Solid Waste Operations Manual WM-SWO-501.

ORNL Liquid Waste Treatment Systems Waste Acceptance Criteria, WM-WMCO201. 
EPA January 1992. Guide to Management of Investigation-Derived Wastes, OSWER Directive No. 9345.3-03 FS.

DOE Order 5400.3, Hazardous and Radioactive Mixed Waste Program, February 22, 1989.

DOE Order 5820.2A, Radioactive Waste Management, September 26, 1988.

M. D. Homan, et al., Waste Reduction Program at Oak Ridge National Laboratory during FY 1990, March 1991, ORNL/TM - 11780.

ORNL Health Physics Manual, Procedures and Practices for Radiation Protection and Radiation Monitoring.

ORNL Health Physics Manual, Procedure RP-5.1, Segregation and Management of Solid Radioactive Waste Material.

ORNL Health Physics Manual, Procedure RP-2.3, Radiological Posting and Labeling.

ORNL Health Physics Manual, Procedure RP-5.1, Segregation and Management of Solid Radioactive Waste Material.

EPA, 40 CFR 261, Identification and Listing of Hazardous Waste.

ORNL/M-8108, On-Site Transportation Manual.

\section{SCOPE AND LIMTTATIONS}

This document applies to ER Program activities at ORNL.

\section{DEFINITIONS}

Area of Contamination (AOC): "An AOC is delineated by the areal extent (or boundary) of contiguous contamination. Such contamination must be continuous but may contain varying types and concentrations of hazardous substance. Depending on site characteristics, one or more AOC's may be delineated. (OSWER Directive No. 9347.3-05 FS) The AOC must be defined to properly apply the Investigative-Derived Waste (IDW) management options."

The Comprehensive Environmental Response, Compensation, and Liability Act of 1980 (CERCLA) as amended by the Superfund Amendments and Reauthorization Act of 1986.

CERCLA Off-Site Policy: Officially titled "EPA Interim Policy for Planning and Implementing CERCLA Off-Site Response Action" and published as 50 FR 45933, November 5,1985 . This policy describes the procedures to be observed when a response action under CERCLA involves off-site storage, treatment, or disposal of hazardous substances. The policy requires that response actions involving treatment, 
reuse, or recycling must be pursued instead of land disposal to the greatest extent practicable. The policy also requires that all storage, treatment, or disposal facilities must be in compliance with Subtitle $C$ of the Resource Conservation and Recovery Act (RCRA) if the substances handled are hazardous wastes, and they must be in compliance with other statutory provisions [such as Toxic Substances Control Act for polychlorinated biphenyls or Atomic Energy Commission (AEC) for radioactive materials] if the substances handled are not categorized as hazardous wastes under RCRA.

Container Packing List (CPL) Form: This form is used to describe a single standard shipping/storage container that holds multiple, separately identified waste items. This type of packing is often. referred to as "lab packing." It differs from a "bulking operation in that the waste items, once packed, retain their original identities and characteristics. The CPL lists the type and identity of the standard shipping/storage container, the identities of all of the waste items packed inside it, and any applicable handling information.

Decontamination Fluids/Agents: Water, solvents, or other fluids and abrasive material (aluminum silicate) used to decontaminate field equipment and instruments and nondisposable personal protective equipment (PPE).

Disposable Equipment: Sampling equipment for use in contaminated areas, it is difficult to decontaminate but inexpensive enough to be discarded following use.

Drilling Mud (or Drilling Fluid): A carefully formulated heavy suspension, usually in water but sometimes in oil, used in rotary drilling. It commonly consists of bentonitic clays, chemical additives, and weighing materials such as barite. It is pumped continuously down the drill pipe, out through openings in the drill bit, and back up into the annulus between the pipe and the walls of the hole to a surface pit where it is screened and reintroduced through the mud pump. The mud lubricates and cools the bit, carries the cuttings up from the bottom, and prevents blowouts and cave-ins by plastering friable or porous formations and maintaining a hydrostatic pressure in the boreholes offsetting pressures of fluids that may exist in the formation. (Dictionary of Geological Terms 1984)

Environmental Restoration Program: The program responsible for the identification, characterization, and cleanup of closed WM sites, spill sites, and other orphaned areas or facilities that either are affecting or have the potential to affect public health and safety or the environment. As the generator of potentially large volumes of waste over the next several decades, the ER Program is responsible for ensuring the safe and regulatory-compliant management of its wastes.

Feasibility Study: A study to develop and evaluate options for RA. The feasibility study emphasizes data analysis and is generally performed concurrently and in an interactive fashion with the remedial investigation (RI), using data gathered during the RI. The RI data are used to define the objectives of the response action alternatives and to undertake an initial screening and detailed analysis of the alternatives. The term may also refer to the report that describes such a study. (40 CFR 300.5) 
Field Staging Area: An area within the AOC where drums and other containers of IDW/remediation waste are stored until the site investigation activities are completed or a final disposal option is selected in a record of decision (ROD). This area may be used until appropriate disposition of all containers is completed consistent with the ROD. The location, usually near the point of waste generation, where the containerized waste materials are staged before the waste is transferred to ORNL Waste Operation.

Generator Certification Official (GCO): The official is required to sign the UCN-2822 and the UCN-16114 form to transfer waste to ORNL Waste Operations. The GCO signature certifies that the waste was packaged in accordance with waste acceptance criteria, ORNL solid low level waste (SLLW) certification program, and SLLW Quality Assurance (QA) Plan requirements, respectively. The GCO must be an Energy Systems employee. Beginning fall 1993, the GCO will be required to sign the proposed forms in Appendix D.

Generator's Signature: Certifies that the waste is packaged in accordance with the waste acceptance criteria, the SLLW QA Plan, and the ORNL Certification Program Plan. This person must be the supervisor (or his/her designee) responsible for placing waste in containers. All persons assigned the responsibilities of containerizing and packaging SLLW must take the ORNL SLLW Generator training course.

Investigation-Derived Waste (IDW): Waste generated during Preliminary Assessment/Site Investigations, RIs/Feasibility Studies, and Remedial Designs that may pose a risk to human health and the environment. IDW may include contaminated PPE; solutions (aqueous or abrasive materials) used to decontaminate nondisposable protective clothing and equipment; drilling mud, cuttings, and purge water from test pit and well installation; soil and other materials from collection of samples; and residues (e.g., ash, spent carbon, well development purge water) from testing of treatment technologies and pump and treat systems.

Laboratory Certification Official (LCO): Responsible for the Waste Certification Program at ORNL.

Project Manager (PM): The person responsible for control of all waste generated during a particular ER site investigation or remediation project.

Public Access Road: A road on the Oak Ridge Reservation (ORR) that is used by members of the general public without their having to gain access through a controlled access point.

Radioactive Waste: Solid, liquid, or gaseous material that (1) contains radionuclides regulated by the AEC of 1954, as amended and (2) is of negligible economic value considering costs of recovery.

Remedial Investigation (RI): A process undertaken to determine the nature and extent of the problem presented by the release of hazardous substances, pollutants, or contaminants. The RI emphasizes data collection and site characterization and 
is generally performed concurrently and in an interactive fashion with the feasibility study. The RI includes sampling and monitoring, as necessary, and includes the gathering of sufficient information to determine the necessity for RA and to support the evaluation of remedial alternatives. (40 CFR 300.5)

Reportable Quantity: Quantities of hazardous materials that may be harmful to human health and the environment, as set forth in 40 CFR 117.3 and 49 CFR 172.101. Transportation or discharges of designated hazardous substances in quantities equal to or greater than the reportable quantities requires compliance with certain DOT or EPA regulations.

Site: A contiguous property unit. Property divided only by a public right-of-way shall be considered one site. There may be more than one manufacturing plant on a single site. RCRA defines "on-site" and "off-site" by whether or not the waste is transferred on a public highway.

Site Inspection: An on-site investigation to determine whether there is a release or potential release of hazardous substance(s), pollutant(s), or contaminant(s) and to determine the nature of the associated threats to public health or welfare or the environment. The purpose is to augment the data collected in the preliminary assessment and to generate, if necessary, sampling data and other field data to determine if further action or investigation is appropriate. (40 CRE 300.5)

Staging: The assembling of waste at a temporary location waiting for appropriate storage, treatment, or disposal.

Very Low Activity (VLA) Waste: Waste that contains no measurable contamination by radiation survey but, because of its past history and inaccessible areas, is judged by ORNL Health Physics to be possibly radioactively contaminated above release limits. Radiation survey results shall not exceed $300 \mathrm{dpm} / 100 \mathrm{~cm}^{2}$ of alpha activity or $0.05 \mathrm{mrem} / \mathrm{h}$ of beta-gamma activity to be classified as VLA waste. This waste must be segregated from SLLW.

Waste Acceptance Criteria: Criteria established to ensure the receipt of acceptable waste materials at a treatment, storage, or disposal site.

Waste Analysis and Characterization: Characterization of waste materials based on historical information or analytical testing. Formalized waste analysis plans are required by RCRA regulations for hazardous waste treatment, storage, and disposal facilities.

Waste Category: A specific category that identifies the waste type [i.e., sanitary, hazardous, mixed, low-level waste, transuranic (TRU), or high-level radioactive].

Waste Consolidation Area: Area for storage, stockpiling, or dispositioning of waste within a lined pit area that is protective of the environment and health and that will be consistent with completion of the final RA. 
Waste Generator: The individual program or organization assigned the responsibility of physically generating and/or sontainerizing and packaging waste.

Waste Item Description (WID) form: This form lists the identity and the characteristics of a waste item, the smallest trackable unit of waste. It also lists the identity of the shipping/storage container into which the waste item may have been placed and any applicable handling information. All of the information on the form is required to register the waste item with the site Waste Management Organization (WMO); however, some of the information is only applicable to specific waste categories.

Waste Pickup Request (WPR) form: This form is used to request the pickup of waste. It lists the identities of self-contained waste items and/or standard waste shipping/storage containers to be picked up for treatment, storage, or disposal. The WPR is submitted to the site WMO along with the corresponding set of WID, Waste Item/Container List, and CPL forms. The WPR is uniquely identified by a request identification barcode placed on the form.

WM Plan: An approved and agreed upon documented plan for characterizing, handling, disposing, transporting, staging, and storing generated waste materials.

Waste Management Organization (WMO) : The operating division at ORNL that is responsible for the day-to-day WM operations.

Waste Storage Area: The location used for storage of waste materials. Areas included are an approved field staging area, a satellite area, a 90-d accumulation area, or a permitted or interim status storage area.

Waste Stream: Source or process from which waste is generated (i.e., coring, drilling, decontamination operations).

Waste Transporter: The indiviaual or organization responsible for transportation of waste materials.

Waste Type: A specific waste type: solid, liquid, sludge, or gas.

Well Cuttings: Rock chips cut by a bit in the process of well drilling and removed from the hole in the drilling mud in rotary drilling or by the bailer in cable-tool drilling. Well cuttings collected at closely spaced intervals provide a record of the strata penetrated. (Dictionary of Geological Terms 1984)

\section{REQUIREMENTS}

As specified in the U.S. Department of Energy (DOE) ER Program WM Plan (DOE/ORO 976), all ER Program participants are required to develop WM plans to identify all waste generating activities and define the steps to be taken to manage and characterize those wastes properly. These plans must be reviewed and approved 
by the appropriate program and plant management staff before initiation of project waste-generating activities.

\section{RESPONSIBILITIES}

This section describes the responsibilitis ror implementation of this procedure.

A Project Manager (PM) or Waste Area Grouping Manager (WAGM)

The PM or WAGM is responsible for ensuring the preparation of the project WM plan and/or checklist, forwarding it for review, coordinating reviewers' comments for disposition, and revising the WM plan and/or checklist if necessary. The PM is also responsible for contacting the site WMO before generating waste and for distributing the approved WM plan and/or checklist to all involved organizations. The PM or WAGM is responsible for approving the project WM plan and ensuring implementation of the approved plan and/or checklist.

1. The PM oi WAGM (or a designated representative) completes the checklist for the site-specific WM plan.

2. The PM or WAGM (or a designee) ensures that the ER methodology or some other approved and documented methodology for generating waste volume estimates is used to determine waste volume values listed in the project WM plan and/or cuecklist.

3. The PM or WAGM (or a designee) contacts the ORNL WMO to determine the best approach for transfer and subsequent storage, disposal, or treatment options.

4. The PM or WAGM (or a designee) is responsible for the preparation of the waste minimization plan or for ensuring that a waste minimization strategy is a part of the project WM plan and/or checklist. The waste minimization plan is to address strategies, objectives, and goals that will be used to evaluate waste reduction methods and technologies.

5. The PM or WAGM (or a designee) is responsible for contacting the plant compliance office for guidance in managing all waste types generated as part of this project.

6. The PM or WAGM is responsible for ensuring that support staff have taken the necessary training to enable them to sign and complete waste disposal forms and to manage specific waste storage areas (if applicable).

7. The PM or WAGM (or a designee) distributes the WM plan and/or checklist for review to the ORNL WMO, the Central ER Division WMO, the Central WM Division, ORNL Environmental Compliance Organization, ORNL ER Program WM coordinator, the LCO, the GCO, and other staff members or organizations that the PM deems appropriate. 
8. The PM or WAGM signs and approves the project WM plan and/or checklist and forwards it to the ORNL ER Program WM coordinator, ORNL WMO, ORNL Environmental Compliance Organization, the LCO, and the GCO for signature approval. This approval signifies agreement with the scope, schedule, and planned treatment, storage, and disposal and other activities outlined in the WM plan and/or checklist.

9. Two to 4 weeks before the generation of waste begins, the PM or a designee should contact the ORNL WMO to reconfirm the availability of storage and disposal facilities.

10. A copy of the approved WM plan and/or checklist will be distributed by the PM to all signers in addition to the Baselining Planning Group, ER Document Management Center, and ER Division WM manager.

B. Central WM Division:

Energy Systems Central WM Division is responsible for providing overall guidance and policies for conducting WM activities at ORR sites.

C. Energy Systems ORNL WMO:

WMO at ORNL is responsible for providing review and approval of the WM plans and/or checklists. The ORNL WMO is also responsible for picking up the waste material from the waste storage area after it has been characterized and proper waste disposal forms have been completed by the generator and the generator certification official. The waste will be transported to an approved storage, treatment, or disposal facility in accordance with regulatory requirements and Energy Systems policies and procedures.

D. ORNL Environmental Compliance Organization:

The ORNL Environmental Compliance Organization provides regulatory guidance for successful completion of the specific project and reviews and approves project WM plans and/or checklists.

E. ER Central WMO:

The Central ER WMO is responsible for providing overall guidance and policies for ER WM activities and for reviewing WM plans and/or checklists.

F. ORNL ER Program WM Coordinator:

The ORNL ER Program WM Coordinator is responsible for implementation of ER WM policies and procedures for ORNL ER Program projects. The ER Program WM coordinator is also responsible for providing guidance in the preparation of WM plans, and reviews and approves all project WM plans and/or checklist. 
G. Generator Certification Official (GCO)

The GCO must be an Energy Systems employee (unless this requirement is waived by LCO) who has successfully completed waste generator training for SLLW, satellite accumulation area, a GCO training module, 90-d accumulation area training, 40-h Occupational Safety and Health Administration training, and radiation worker training. Some of these training requirements naay be waived depending on project needs. A waiver may be requested from the ORNL ER field coordination manager.

1. The GCO serves as the interface between the project, the ORNL LCO, and the ORNL WMO in addressing generator problems and waste certification requirements.

2. The GCO initiates and completes the GCO section of the UCN-2822 form "Request for Storage or Disposal of Radioactive Solid Waste or Special Materials" (which will be replaced by the proposed forms in Appendix D during fall 1993).

3. The GCO certifies by signing the UCN-16114, "Log-in Data Sheet for Generators of Solid Low Level Waste" (which will be replaced by the proposed forms in Appendix D during fall 1993), that the waste was packaged in accordance with the waste acceptance criteria, the ORNL SLLW certification program plan, and SLLW QA plan requirements.

4. The GCO ensures (beginning September 1993) that each waste item packed in the container is identified with a properly completed WID and attached barcode label, verifying that the container is properly sealed and labeled, and that the waste package meets all applicable site criteria for transfer to the site WMO.

5. The GCO certifies that the information on the CPL is complete and accurate; that the waste package complies with waste acceptance criteria of the treatment, storage, or disposal facility to which it is being submitted; and that the waste was packaged by individuals with appropriate training. See Appendix D for the proposed forms that will be implemented fall 1993.

6. The GCO shall ensure that generation of wastes follows a documented and WM-approved certification program.

7. The GCO shall monitor waste generating and managing activities against an approved certification program by periodic inspections or audits.

8. The GCO shall review or approve, as specified: nonconformance reports and trends, log-in sheets, training records, and facility-specific procedures for the proper packaging and handling of SLLW.

9. The GCO reviews and approves all WM plans and/or checklists. 
10. The GCO ensures that SLLW is properly classified, adequately characterized, and packaged in accordance with project WM plan and/or checklist and applicable waste acceptance criteria.

11. The GCO or a designee makes arrangements with waste operations for pickup and transfer of waste to the disposal, storage, or treatment facility.

12. The GCO maintains a copy of all waste disposal request forms on file.

H. Laboratory Certification Official (LCO)

The LCO is responsible for implementing and managing the ORNL SLLW Management Program.

1. The LCO reviews and approves project WM plans and/or checklists.

2. The LCO approves all plans related to the generation of TRU wastes.

I. Generator:

The generator is the responsible Energy Systems organization, prime contractor, subcontractor, or person that is physically generating the waste during D\&D, RI, RA, or any waste-generating activities associated with ER Program activities.

1. The generator is responsible for properly containerizing, packaging, and segregating all waste generated as part of the project, in addition to fulfilling other requirements set forth in the solid waste storage area waste acceptance criteria and the WM plan.

2. The generator is responsible for signing column 15 of the UCN-16114 (which will become obsolete during fall 1993), "Log-in Data Sheet for Generators of Solid Low Level Waste." Beginning fall 1993, the generator is to complete and sign Sect. I of the WID form (see Appendix D).

3. The generator is responsible for completing all parts of the UCN-16114, "Log-in Data Sheet for Generators of Solid Low Level Waste," for which the generator provided information.

4. All persons responsible for packaging or placing waste in containers as part of RI or RA activities are required to take ORNL SLLW generator training unless this requirement is waived by the ORNL LCO.

5. The generator is responsible for minimizing SLLW production.

6. The generator is responsible for attending and maintaining currency in ORNL SLLW generator training and facility specific training before generating SLLW. 
7. The generator interfaces with the GCO to ensure that any issues in SLLW characterization is promptly brought to the attention of the responsible individuals and that any new certification requirements or procedures are promptly instituted.

8. The generator provides, as much as possible, the necessary data for certification of SLLW, including collecting and documenting the data on the log-in data sheet.

9. The generator will assist the GCO in completing the WPR and the CPL forms. These forms will become effective fall 1993. See Appendix D for the proposed forms.

\section{REQUIRED RECORDS AND CHANGE CONTROL PROCEDURES}

If significant changes are identified that will impact waste volumes; estimates; and storage, treatment, and disposal facilities in addition to schedule changes, the PM must revise and reissue the project WM plan for review and approval before project initiation. The same review and approval procedures apply for revision of the plan as applied for the original development and issuance.

\section{ADMINISTRATION}

The ORNL ER WM coordinator is responsible for the interpretation of this document. The implementation of the procedure described herein is the responsibility of the managers or supervisors of staff members who perform the activities described in this document. 


\author{
Appendix A \\ Outline for Project \\ WM Plan (Project WM Umbrella Document)
}




\section{OUTLINE}

1. Introduction
$1.1 \quad$ History of Site
1.2 Purpose of Activity
1.3 Scope of Activity

2. Line of Responsibilities
2.1 Prime/Subcontractors
2.2 Martin Marietta Energy Systems, Inc. (Energy Systems)
2.3 Interface Responsibilities Between Prime/Subcontractor and Energy Systems
2.4 Generator
2.5 Generator Certification Official
2.6 Site Safety and Health Officer
2.7 Etc.

3. Waste Generating Activities
3.1 Soil Sampling
3.2 Drilling, Boring
3.3 Well Development, Sampling, Purging, or Upgrade
3.4 Decontamination
3.5 Construction
3.6 Sediment Sampling
3.7 Surface Water Sampling
3.8 Etc.

4. Types and Volume of Waste (solid, liquid, sludge, sediment, PPE, asbestos, metal, etc.)
4.1 Conventional
4.2 Radiological
4.3 Hazardous
$4.4 \quad$ Mixed
4.5 Construction
4.6 Etc.

5. Applicable WM Activities
5.1 In situ vitrification
$5.2 \quad$ Capping
5.3 Segregating
5.4 Containerizing
5.5 Transporting
5.6 Storing
5.7 Packaging
5.8 Labeling 
5.9 Disposing

$5.10 \quad$ Stockpiling

5.11 Monitoring

5.12 Consolidating

5.13 Etc.

6. Waste Minimization Strategies
6.1 Waste Generating Strategies
6.2 Equipment Type and Size
6.3 Segregation of Waste Forms
6.4 Innovative Decontamination Operation
6.5 Implementing EPA's Comprehensive Environmental Response,
6.6 Etc.

7. Environmental Health and Safety

7.1 Contamination Control

7.2 Personnel Exposure Control

7.3 Airborne Activity Control

7.4 Spill Control

$7.5 \quad$ Etc.

8. Waste Temporary Storage/Accumulation Area Training Requirements
8.1 Type of Waste Staging Area
8.2 Compliance Requirements
8.3 Environmental, Safety, and Health (ES\&H) Requirements
8.4 Training Requirements to Manage Area(s)
8.5 Training Requirements to Complete/Sign Waste Disposal Forms
8.6 Personnel That Will Manage Area(s)
8.7 Emergency Evacuation Routes/Procedure

9. Transfer of Waste to Energy Systems
9.1 Waste Acceptance Criteria
9.2 Completion of Waste Disposal Forms
9.3 Characterization of Waste
9.4 Sampling Plan
9.5 Interface Responsibility

10. Quality Assurance
10.1 Surveillance Program
10.2 Reporting System for Noncompliance
10.3 Corrective Action
10.4 Maintaining Records 


\section{Appendix B}

\section{ORNL ER Program WM Checklist and Instructions}

(The checklist will be revised when a version of the Energy Systems Waste Request Profile Sheets/Request for Disposal forms is finalized.) 


\section{Waste Management Planning Checklist ORNL Environmental Restoration Program (Page 1 of 11)}

\section{Date}

1. Project Name:

Expected Start/Completion Date:

Responsible Project/WAG Manager:

Phone:

Address:

Location of Project (WAG, building, street, etc.):

Organization/Subcontractor Performing Waste Generation Task:

Work Order Number for Waste Management/ P\&E Activities:

2. Responsible field ORNL Construction Engineer/Prime or Subcontractor

Phone:

Address:

Responsible field and ES\&H Supervisor:

Phone:

Address:

Please attach a drawing or sketch of the proposed location(s) of the waste-generating activities to this document. (unless sketch is in project waste management plan) 


\section{Waste Management Planning Checklist ORNL Environmental Restoration Program (Page 2 of 11)}

3. Project Description (site history and scope of project):

4. Completion and Signatures of Waste Management Forms:

Individuals who have not taken the proper training authorizing them to sign Waste Disposal forms should contact Kory Gabrielsen at 576-4374, for Specific Training Requirements.

A. Request for Storage or Disposal of Radioactive Waste or Special Materials (Appendix C, attachment 1):

Form UCN-2822 1

Requester's Name (GCO, MMES Employee)

Health Physics Technician's Name

B. Log in Data Sheet (Appendix C, attachment 2):

Form UCN-16114

Column 15: Supervisor or designee of waste packaging/containerization activities (generator)

Notes 2, 3: GCO

\footnotetext{
${ }^{1}$ These forms will be phased out during fall 1993. See Appendix D for the proposed forms that will be implemented beginning fall 1993 .
} 


\section{Waste Management Planning Checklist ORNL Environmental Restoration Program (Page 3 of 11)}

C. Request for Disposal of Hazardous Waste Material (Appendix C, attachment 3):

Forms UCN-13698 ${ }^{2}$ and UCN-13698 $\mathrm{A}^{2}$

Subcontractor/Prime Contractor

Waste Generator Name

Health Physics Technician's Name

MMES Waste Generator Name

D. Request for Disposal of Asbestos or Material Containing Asbestos (Appendix C, attachment 4):

Form UCN-13386 ${ }^{2}$

Requester's Name

E. Request for Disposal of Sanitary/Industrial Waste and Spoil Material

Form UCN-2109/Trip Ticket ${ }^{2}$ (Obtain form and trip ticket from ORNL Hazardous Waste Operation Group).

Authorized Name

2These forms will be phased out during fall 1993. See Appendix D for the proposed forms that will be implemented beginning fall 1993 . 


\section{Waste Management Planning Checklist ORNL Environmental Restoration Program (Page 4 of 11)}

5. Person or organization responsible for completing the weekly Environmental Restoration Waste Management Program Generated Waste form (Appendix C, Attachment 7):

\section{Name}

6. Organization or person responsible for providing, MMES, prime or subcontractor with characterization data for waste transfer or dispositioning:

7. Organization or person responsible for obtaining samples from waste containers and transporting those samples to the analytical laboratory for characterization purposes:

8. Describe sampling plan for taking samples (from waste containers or the area of contamination) that are to be sent to the lab for characterization information which will be used in completing the waste disposal forms.

9. Organization or person responsible for performing analysis on waste samples for characterization purposes:

10. What analysis will be requested to characterize the waste? (Be Specific) 


\section{Waste Management Planning Checklist ORNL Environmental Restoration Program (Page 5 of 11)}

11. List the process knowledge available to characterize the waste: (Provide the Name of Specific Reference Material and Where It Can Be Located)

12. Is the available process knowledge enough to properly characterize the waste with out having to perform analysis on the waste? Y/N/NA (Please Circle)

13.

$\underline{\text { Waste Stream/Source }}^{a}$ Type $^{b}$ Category $^{c}$ Volume (cubic feet) ${ }^{d}$ Suspected Contaminates

(1).

(2).

(3).

(4).

(5).

(6).

${ }^{a}$ Coring, drilling, deconning, surface/ground water sampling, protective equipment, well puring, etc.

${ }^{b}$ Liquid, metal, plastic, sediment, sludge, soil, etc.

${ }^{\circ}$ Classified, clean, construction, hazardous, mercury, mixed, nonhazardous, radiological, TRU, TSCA, etc.

${ }^{d}$ ER Methodology for generating waste volume estimates is to be used in estimating waste volumes. Unless if you have an approved alternate methodology for estimating waste volume.

What Methodology was used to estimate your waste volumes? Be specific.

14. Will a spill control kit be on-site during waste generation activities? Y/N/NA (Please Circle) 


\section{Waste Management Planning Checklist ORNL Environmental Restoration Program (Page 6 of 11)}

What will the spill control kit consist of? (Be specific)

Is a first responder emergency action plan in place, in case of spill or a line puncture? This means in addition to contacting Laboratory Protection (911). Please be specific.

15. What organization or person will be assigned the responsibility of properly containerizing the waste, labeling the waste containers, and labeling and bagging contaminated material?

16. Which of the following areas will be required to temporarily store the project waste until the waste can be transferred to ORNL Waste Management Operations?

A Radiological Waste Storage Area: Y/N/NA (Please Circle)

Location:

Responsible organization or person that will manage area:

B. 90-Day Siorage Facility for hazardous or mixed waste: YN/NA (Please Circle)

Location:

Responsible organization or person who will manage area:

C. Satellite Accumulation Area: Y/N/NA (Please Circle)

Location:

Responsible organization or person that will manage area:

D. What is in place to protect the structural integrity and weatherability of drums and B-25 boxes. Be specific. (refer to instructions for assistants.) 


\section{Waste Management Planning Checklist ORNL Environmental Restoration Program (Page 7 of 11)}

E. If any of the above areas will not be used to manage the waste, please give specific details to how this waste will be manage.

Examples: stockpiling, solidification, incineration, synthetic or clay linings, in situ vitrification, leave waste in area of contamination, etc.

Have training requirements (e.g., Satellite Accumulation Area and 90-Day Accumulation Area) been fulfilled to manage the storage area? Y/N/NA (Please Circle)

17. Have you spoken to ORNL compliance personnel pertaining to your requirements for managing a temporary satellite, 90-day or radiological waste storage area? Y/N/NA (Please Circle)

Person Contacted

Phone

List the specific requirements:

18A. Can The ORNL Hazardous Waste Group take charge of the hazardous or mixed waste generated? Y/N/NA (Please Circle)

L: not now, when?

List any specific requirements:

Volume of Waste (cubic feet):

Person Contacted

Phone

18B. Can the Solid radioactive Waste group accept the volume of radiological waste that will be generated? Y/N/NA (Please Circle)

If not now, when? 


\section{Waste Management Planning Checklist ORNL Environmental Restoration Program (Page 8 of 11)}

List specific requirements:

Volume of Waste (cubic feet):

Person Contacted

Phone

18C. Can the Liquid Gaseous Waste Group accept the liquid waste that will be generated? Y/N/NA

If not now, when?

List any specific requirements:

Volume of Waste (cubic feet):

Person Contacted

Phone

18D. Do you plan to generate any brine solution, sludge or sediment waste, if so how will you manage this waste? Give specific details.

18E. Will any large volumes (greater than $96 \mathrm{ft}^{3}$ ) of uncontaminated spoils been generated? Y/N/NA

If yes, give specific details how you plan to manage those spoils.

18F. For waste that cannot be managed by any of the above ORNL Waste Operation Groups, what is your alternative for managing the waste? Give specific details.

19. Will any TRU/or TRU Mixed Waste be generated? Y/N/NA If yes, the Laboratory Certification Official is to be consulted, before any TRU waste is generated. 


\section{Waste Management Planning Checklist ORNL Environmental Restoration Program (Page 9 of 11)}

List the specific requirements for managing TRU/and or TRU Mixed Waste.

Person Contacted

Date

20. What organization or person will be responsible for transporting the waste from the generation area to the temporary waste storage area to await final pickup by Martin Marietta Energy Systems (MMES)?

Describe the route that will be used transport waste to the temporary waste storage area, treatment, facility, or disposal facility:

21. Will ORNL Waste Management Operations be responsible for transporting waste from site of waste generation or the waste storage area to an MMES storage, treatment or disposal facility? ORNL Waste Operation does not normally pick up waste from offsite. YN/NA (Please Circle)

\section{$\overline{\text { MMES Person Contacted }} \quad \overline{\text { Phone }}$}

Give specific details regarding who or what organization will be transporting the waste from the site of waste generation or waste storage area to an MMES storage, disposal, or treatment facility.

22. For waste that is generated offsite, who or what organization will transport that waste to ORNL Waste Operation? Give specific details as to how this waste will be transferred to ORNL Waste Operations? 


\section{Waste Management Planning Checklist ORNL Environmental Restoration Program (Page 10 of 11)}

23. A Will waste require transporting over public roads? Y/N/NA (Please Circle) If yes, DOT regulation must be adhered to.

B. Will waste require transporting over DOE roads before 9 a.m. and after 4 p.m.? If yes, DOT regulation must be adhered to.

C. List the Department of Transportation issues that are of concern in transporting this waste: (Be specific)

D. Have you communicated those concerns of transporting the waste and associated resolutions to ORNL Transportation Operation Management Department and received their concurrence of how the waste may be transported? Y/N/NA (Please Circle)

Person Contacted

Phone

E. List the resolutions to those concerns:

24. Identify your waste minimization techniques in that will be implemented during this task. Provide specific details.
Segregation
Decontamination
$\square$ Waste Handling (Spill Control)
Compaction
$\square$ Material Recycle (Solvents, Wash Waters)
Solvent Substitution
$\square$ Material Reuse (Solvents, Wash Waters)
Sludge Dewatering
Selection of PPE
$\square$ Cutting Fluids Recovery
Selection Of Equipment
$\square$ Other

Description of Special Techniques: 


\section{Waste Management Planning Checklist ORNL Environmental Restoration Program (Page 11 of 11)}

25. Attach any additional information that will give further clarification of your waste management plan.

\section{Approvals}

Signature Project Manager

Date

$\overline{\text { Generator Certification Official }}$

Date
ORNL Waste Management

Operation Organization

ORNL Waste Management Plan

Document Number

Date

ORNL Environmental Restoration

Program

Date

Environmental Compliance and

Documentation

Date

Laboratory Certification Official 


\section{INSTRUCTIONS FOR COMPLETING THE ORNL ER PROGRAM WM PLAN CHECKIIST}

The PM or a designated representative is responsible for completing the checklist and issuing the plan to the applicable organizations for review and/or approval. Completing the checklist will fulfill the basic requirements for a WM plan for ORNL Waste Operations and ORNL ER Program if a project WM plan is in place. Any additional information or drawings that may give further clarification of the scope of the project WM activities should be included as part of this document.

The following is a list of instructions for completing the WM Plan Checklist:

1.

Project Name: Plant ER Program project/task designation.

Expected Start/Completion Date: The expected or scheduled start and completion dates for the generation of waste.

Responsible PM or WAGM: Name of PM or WAGM.

Location of Project: WAG or specific building or site location.

Work Order Number for WM and Plant and Equipment activities: Account number for WM charges.

2.

Construction Engineer: ORNL Construction Engineer or prime or subcontractor in the field overseeing the project activities on a daily basis.

ES\&H Field Supervisor: Person responsible for all environmental, health, and safety aspects of the project, including environmental protection, fire protection, occupational health monitoring, construction safety, industrial hygiene, and radiation and contamination control.

3.

Project Description: Detailed information pertaining to the site history, contamination, and the scope of activities to occur under this WM plan. A project description is not required if information is given in the project WM plan.

4.

Completion and Signatures of WM Forms: PM is to ensure that a minimum of two individuals have had training authorizing them to sign various waste disposal forms and manage temporary waste disposal areas (if applicable). All personnel assigned the tasks of packaging and placing waste in containers are required, at a minimum, to participate in the ORNL SLLW Generator Training. A variance from this particular requirement can be requested from the ORNL SLLW LCO. 
S.

ER WM Program Generated Waste Report: This report should document the total volume of waste produced in each WAG/OU, and it must be completed weekly by the PM or a designated representative. This report should be mailed to ORNL ER WM Coordinator as well as copies of Requests for Disposal forms and copies of Laboratory Analysis Reports, which should be attached to the Specific Request for Disposal forms.

6.

The Organization or Person Responsible for Providing Energy Systems, Prime, or Subcontractor with Characterization Data for Waste Disposal: The PM or a designee is responsible for providing the characterization data in a condensed format to the GCO. SLLW shall be characterized to identify actual physical and chemical characteristics, weight, volume, and major radionuclide content and concentrations. Major radionuclides are those that contribute $5 \%$ or more of the total package activity. Waste is to have a curie content determination. The following methods may be used to determine curie content of wastes:

A. Process knowledge: Must be based on documented evaluation of the waste stream. This information must be available for review.

B. Isotopic and/or chemical analysis.

C. Direct gross alpha, beta, and gamma measurements: Measurement of alpha, beta, or gamma emissions from a containerized package may be used to determine radionuclide concentrations, provided that adequate information is known about the radionuclide inventory and isotopic ratio to make reliable assumptions as to the source of radiation. Process knowledge and control must be used if the certification of the waste relies on gross activity or activity in disintegrations per minute. The type of instrument and methud to be used to obtain doses rate should be specified. The actual formula and assumptions made in estimating curie content shall be listed in the WM plan.

7.

The organization or person responsible for obtaining samples from waste containers and transporting those samples to the analytical laboratory for characterization purposes: The PM or a designee has this responsibility.

8.

Describe sampling plan for taking samples (from waste containers or the area of contamination) that are to be sent to the laboratory to obtain characterization information that will be used in completing the waste disposal forms: The PM or a designee has this responsibility.

9.

The organization or person responsible for performing analysis on waste samples for characterization purposes: To be determined by the PM. 
10.

The analysis requested to characterize the waste will be determined by the PM in consultation with the GCO and the LCO.

11.

List the process knowledge available to characterize the waste: The PM or the GCO should consult with ORNL WM LCO and the ORNL Compliance Organization to decide whether or not the information available is sufficient to characterize the waste for disposal without further laboratory analysis.

12.

Reference number 11

13.

Waste stream/source is defined as the source or process from which the waste will be generated, such as drilling, coring, deconning, etc. This is to be completed by the PM.

14.

A spill control kit is required on all sites involving drilling, coring, auguring, and any other operation that may generate liquid or sludge waste. A spill control kit at a minimum should contain an adequate supply of absorbent pads, chemical resistant gloves, a shovel, and a broom. The outside of the spill control kit container shall display "spill control kit" in large lettering on the outside of the container. Please consult with the ORNL Compliance Department for further requirements pertaining to a spill control kit.

15.

ES\&H site supervisor oversight responsibility is to adhere to ORNL health physics procedures for properly labeling, bagging, and managing contaminated material.

16A-C.

The PM or the GCO must determine what type of waste storage areas will be required for the project and ensure that their team members have had proper training to manage the specific waste storage areas and sign and complete the waste disposal forms. Members of the compliance department shall be consulted for requirements for managing waste storage areas.

The PM is to determine the physical location of the staging area to be used upon generation of the waste materials. Include reference to any special requirements for the staging area including, as a minimum, container type (55-gal drum, B-25 box, wooden box), signs, container labeling, and containment measures.

$16 \mathrm{D}$.

Corrosion protection is to be addressed because the storage of sludge, soil, and similar material with significant water content has the potential of aggressively attacking the standard drum and B-25 containers that is not protected with epoxy paint, plastic liner, or other water resistant material. 
17.

Someone from environmental compliance and documentation must be consulted.

18A.

The ORNL Hazardous Waste Operation Group supervisor is to be consulted concerning storage facilities for handling any volume of hazardous or mixed waste that may be generated. If there is no storage space or a written and approved contingency plan to manage the waste, this type of waste form must not be generated.

$18 \mathrm{~B}$.

The ORNL Radioactive Solid Waste Group supervisor is to be consulted on the availability of disposal and storage space for solid radioactive waste. If there is no storage, disposal space, or a written and approve contingency plan to manage the waste, this type of waste form must not be generated. The ORNL Solid Waste Group is not responsible for handling nonradioactive materials.

$18 \mathrm{C}$.

The ORNL Liquid Gaseous Waste supervisor is to be consulted pertaining to disposing liquid waste that may be generated. If there is no storage, disposal, treatment facility or a written and approved contingency plan to manage this waste form, then this waste form must not be generated.

$18 \mathrm{D}$.

Sediment and sludge waste is not normally managed by the ORNL Radioactive Solid Waste Group, nor the ORNL Liquid Gaseous Waste Group unless these waste forms have been dewatered. If this type of waste is expected to be generated, a written contingency plan is required to be in place that addresses how this waste form(s) will be managed or placed in a form that can be accepted by ORNL Waste Operations Group.

$18 \mathrm{E}$.

K. G. Edgeman of the ORNL hazardous Waste Operation Group is to be contacted for direction in managing and disposing uncontaminated spoils.

19.

There are special considerations that need to be addressed before any TRU or TRU-mixed waste is generated. The specific requirements will come from the ORNL LCO and WMO.

20.

Waste Transportation Requirements: Describe the expected routes to be used to transport waste materials from the site of generation to storage, treatment, or disposal facilities. If public access roads are involved, DOT regulations must be considered and will affect material packaging, labeling, and shipping. Computation of reportable quantities of regulated hazardous substances may be necessary to determine whether DOT regulations apply. Consult with ORNL Transportation Operation Management Department. 
21.

Normally, Energy Systems does not pick up waste before it is characterized, nor does it normally pick up waste off-site.

22.

Refer all transportation questions to ORNL Transportation Operation Management Department.

23.

Refer all transportation questions to ORNL Transportation Operation Management Department.

24.

All projects are to have a waste minimization plan or section within the WM plan that addresses specific details in waste minimization practices that will be implemented for this task or project.

25.

Attach any other documentation that will enhance the understanding of the WM plan and/or checklist. 


\section{Appendix C}

ORNL/ER Program WM Forms

and Instructions for Completing the Forms 


\title{
ORNL/ER PROGRAM WM FORMS AND INSTRUCTIONS FOR COMPLETING THE FORMS
}

\author{
Attachment 1 \\ UCN Form-2822, \\ Disposal of Radioactive Solid Waste or Special \\ Materials
}

Attachment 2

UCN Form-16114, $1{ }^{1,2}$, Log-In Data Sheet for Generators of Solid Low-Level Waste

Attachment 3

UCN Tag-2785, Radiation Hazard Tag

Attachment 4

UCN Tag-13075', General Low-Levei Radioactive Compactible Waste Tag (only required for compactible waste)

Attachment 5

UCN Form-136982, Request for Disposal of Hazardous and Mixed Waste

Attachment 6

UCN Form-13386, ${ }^{1,2}$ Request for the Disposal of Asbestos or Material Containing Asbestos

Attachment 7

UCN Form-19611, Environmental Restoration Waste Management Program Generated Waste Form Summary Report

Attachment 8

UCN form-19665, Environmental Restoration Program Waste Generation Forecast Form

Attachment 9

TX-5352 Form ${ }^{2}$, Log-In Data Sheet for Packaging TRU Waste

Attachment 10

TX-5352A Form², Log-In Data Sheet for Packaging TRU Mixed Waste

Attachment 11

UCN Form-2109², Request for Transfer, Storage, or Disposal of Waste

\footnotetext{
${ }^{1}$ Copies of the completed forms UCN Form-16114, UCN Form-2822, and UCN Form-13386 must be filed with the GCO for the "Life of the Facility."

${ }^{2}$ Effective fall 1993, these waste disposal forms and tags will be phased out. See Appendix D for the new forms that will be implemented during fall 1993.
} 
ATTACHMENT 1

UCN Form-2822, Request for Storage or Disposal of Radioactive Solid Waste or Special Materials 


\section{INSTRUCTIONS FOR COMPLETING THE UCN-2822 FORM REOUEST FOR STORAGE OR DISPOSAL OF RADIOACTIVE SOLID WASTE OR SPBCIAL, MATERIALS}

The following information is to assist you in the proper completion of the UCN.2822 Form. The form must be completed in ink

Dater Date waste is being sent to burial ground.

Origin of W/te: Building where waste was generated. Always use a building or area number. Comment section may be used to further describe the origin of waste.

G.C.O. Simathe: Legible signature of Generator Certification Official. Avso include G.C.O. Badge Number. Division Code, Phone Number, and Mailing Address. Must be Martin Marietta employee.

Total Volume: Total volume of waste inciuding the outer package in cubic fect.

Combustible Volume: Amorint in cubic feet of the total volume that is combustible.

Weight: Total weight of was\%, and container in pounds.

UCN 2681 Na: Only applicable if waste has a UCN-2681, ORNL Nuclear Materials Intra-Laboratory Transfer.

Charee/Wort Order No: Active charge or work order number.

Waste Cram Coder Choose onty one of the following codes that best describes the waste.

\begin{tabular}{lll} 
Code & & Code Description \\
\hline 1 & - & Contact Hasided TRU or U-233 $>100 n C i / g r a m$ \\
2 & - & Uranium/horium \\
3 & - & Fission Product. \\
4 & - & Induced Activity \\
5 & - & Tritium \\
6 & - & Remote Handled TRU or U-233 $>100 \mathrm{nCi} / \mathrm{gram}$ \\
7 & - & TRU or U-233 $<100 \mathrm{nCi} / \mathrm{gram}$. \\
9 & - & LandfillSuspect \\
A & - & Asbestos. contaminated and suspect/orown tag. \\
P & - & Resource lead
\end{tabular}

Waste Type Code: Choose only one of the following codes that best describes the waste:

\begin{tabular}{ll} 
Code & Code Description \\
\hline BW & Biological Waste \\
CE & $-\quad$ Contaminated Equipment \\
DD & Decontamination Debris \\
DS & Dry Solids \\
SS & Solidified Sludge
\end{tabular}


RCRA Precent? IYMD: indicate presence/abeence of RCRA materials (TRU waste pac: ages only).

Asbestos: For radiosctively contaminated asbestos material. Enter preassigned number from the form UCN-13386, Request for the Disposal of Asbestos or Material Containing Asbetstos.

Pactare Type Code: Choose one code each that best describes the inner and outer pacikages. If the containers listed do not provide adequate size or shielding. other containers may be used subject to the approval of Radioactive Solid Waste Operations supervisor:

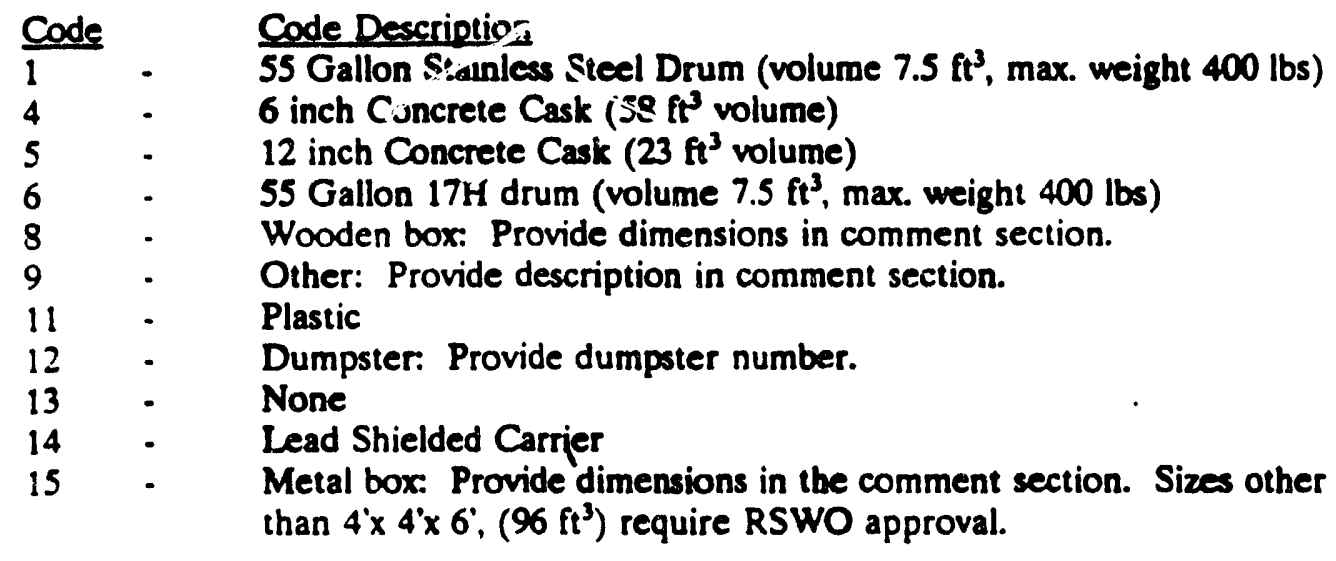

Principal Isotopes Contributing More Than s\% Totel Pretone Activits. List the principal isotupes and their quantity in Curies and/or grams in the appropriate columns as in the following examples:

Cs-137 or Sr-90, etc. 1.0E-4 or $1 \times 10^{-4}$

List the quantity of Fissile isotopes and Uranium/Thorium in grami, all other quantities in curies. Totals for the isotopes from the accompanying log-in data sheets (TX-5352 or UCN16114) should be represented in the appropriate column. Log-in data sheet(s) must be complete. approved, and attached to.the UCN-2822.

General Weste DexciptionkComments: Provide a brief description or general comments, as appropriate.

R-diation Protection Sextion: This section must be completed by Radiation Protection before the waste will be 2 cepted by RSWO. Transferable contamination and dose rate data is for the exterior of the outer package. Dose rate for both the surface, and at one meter, must be provided for the exterior of the outer package. Provide survey instrument serial number(s).

Radioactive Solid Weate Operation: Approval of RSWO Field Representative. Required before waste can be accepted. G.C.O. section (including Principle Isotopes) and Radiation. Protection Section of the UCN-2822 must be complete. 
REQUEST FOR STORAGE OR DISPOSAL OF RADIOACTTVE SOLID WASTE OR SPECLAL MATERLALS

GCO Section

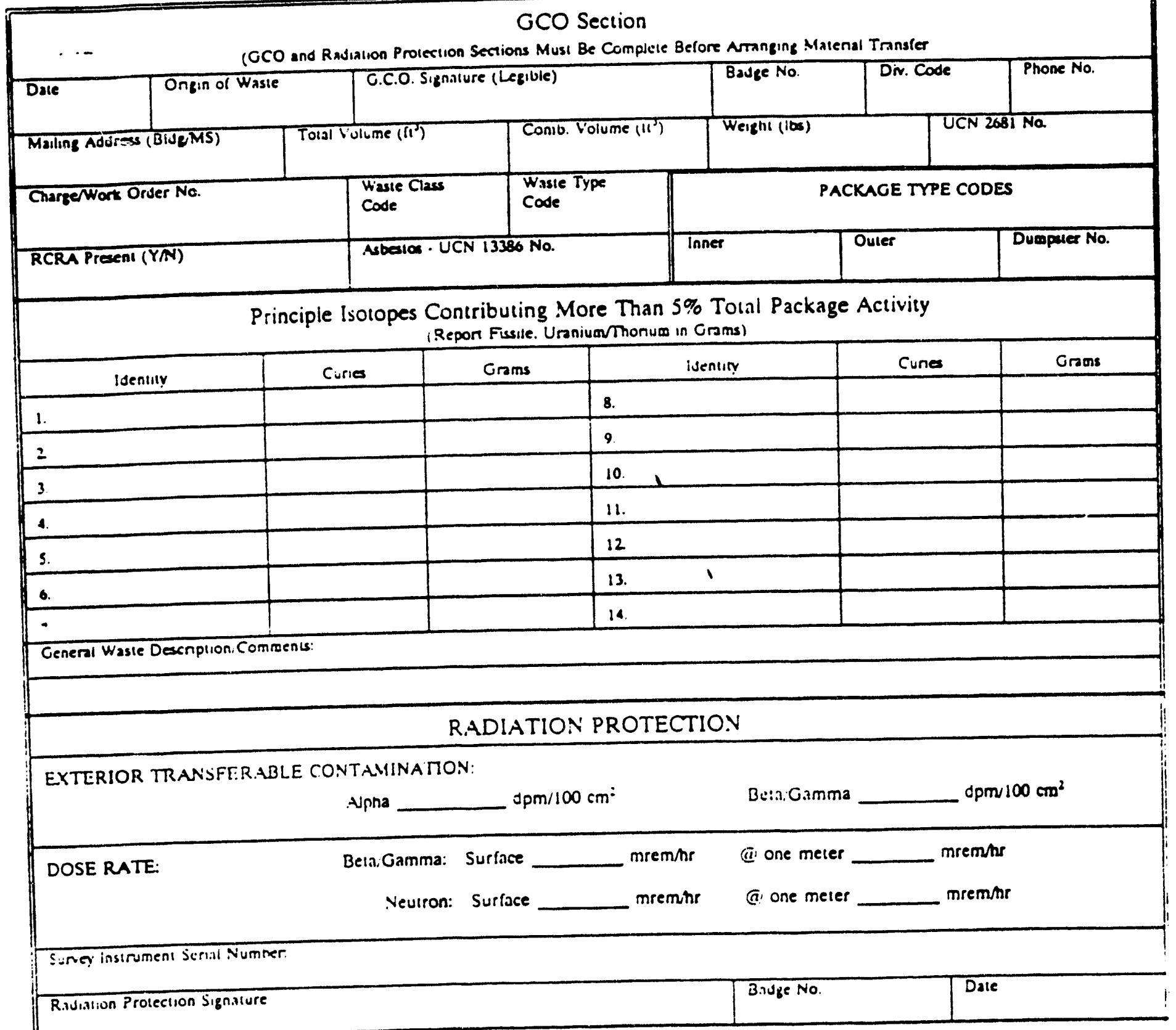

RADIOACTIVE SOLID WASTE OPERATIONS

\begin{tabular}{|l|l|l|}
\hline RSWU Signalure & Bajge No. & Daie \\
\hline Basic Descrpition (DUI) & Cost Symbol & Adjusimeat \\
\hline
\end{tabular}

Cumments

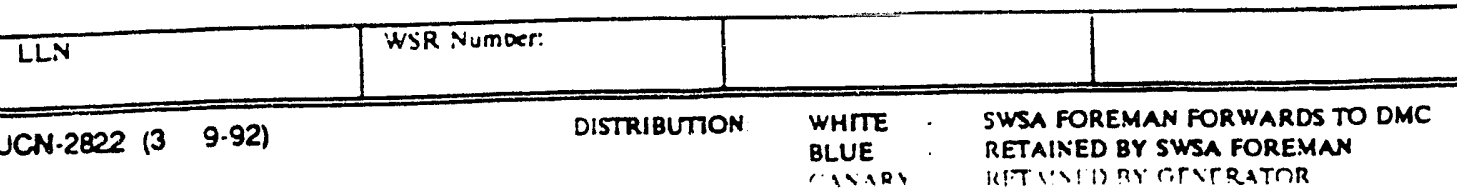




\section{ATTACHMENT 2 \\ UCN Form-16114, Log-In Data Sheet for Generators of Solid Low-Level Waste}




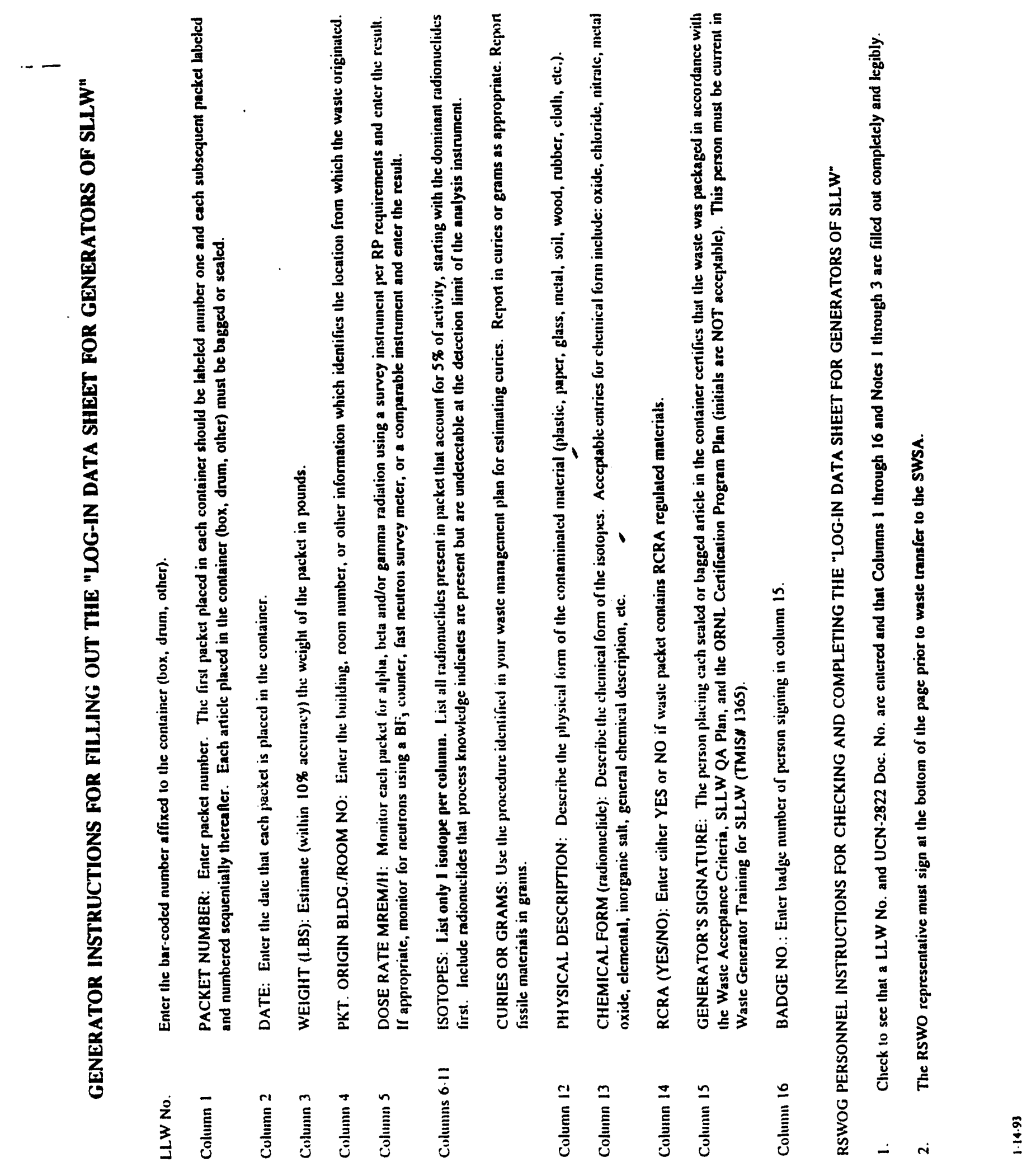




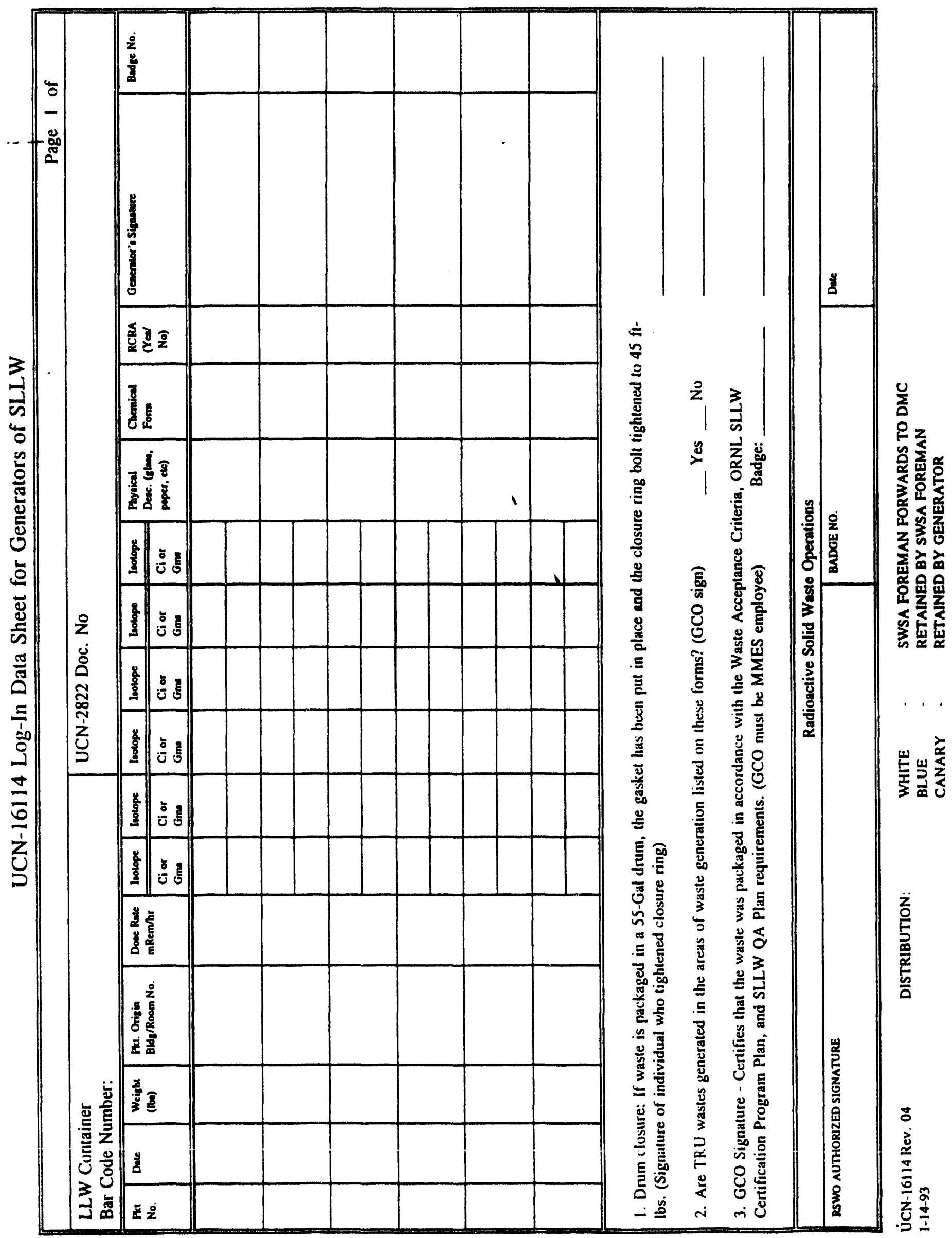




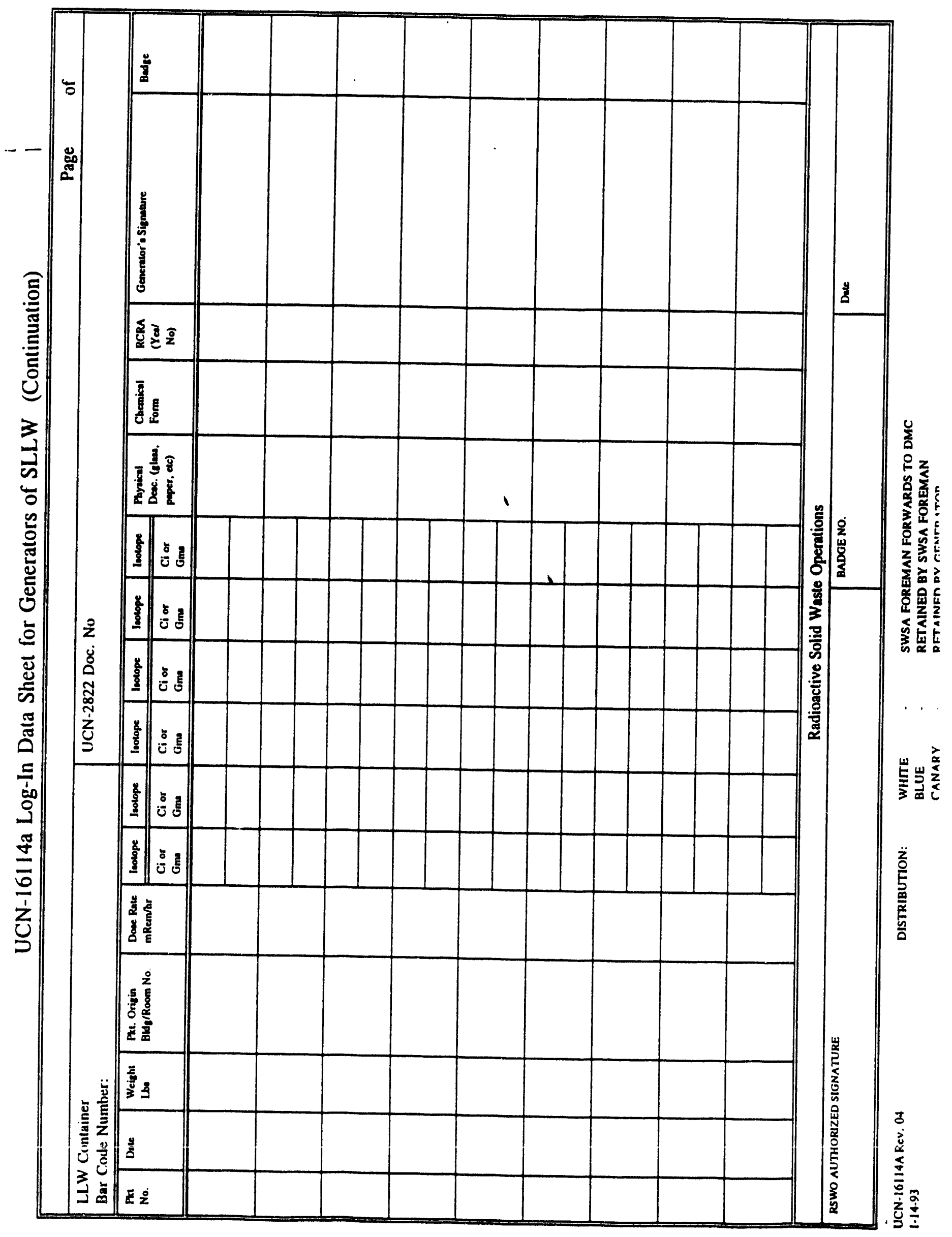




\section{ATTACHMENT 3}

\section{UCN Tag-2785, Radiation Hazard Tag}


This tag designates a radiation source or contaminated item. The description of the source or item and its radiation and/or contamination levels are noted on the tag. This tag may also be used to temporarily post a radiation area, a regulated area, or a contamination area. This tag is completed by the designated Health Physics technician and placed on the radiological compactible waste dumpster for waste pickup.
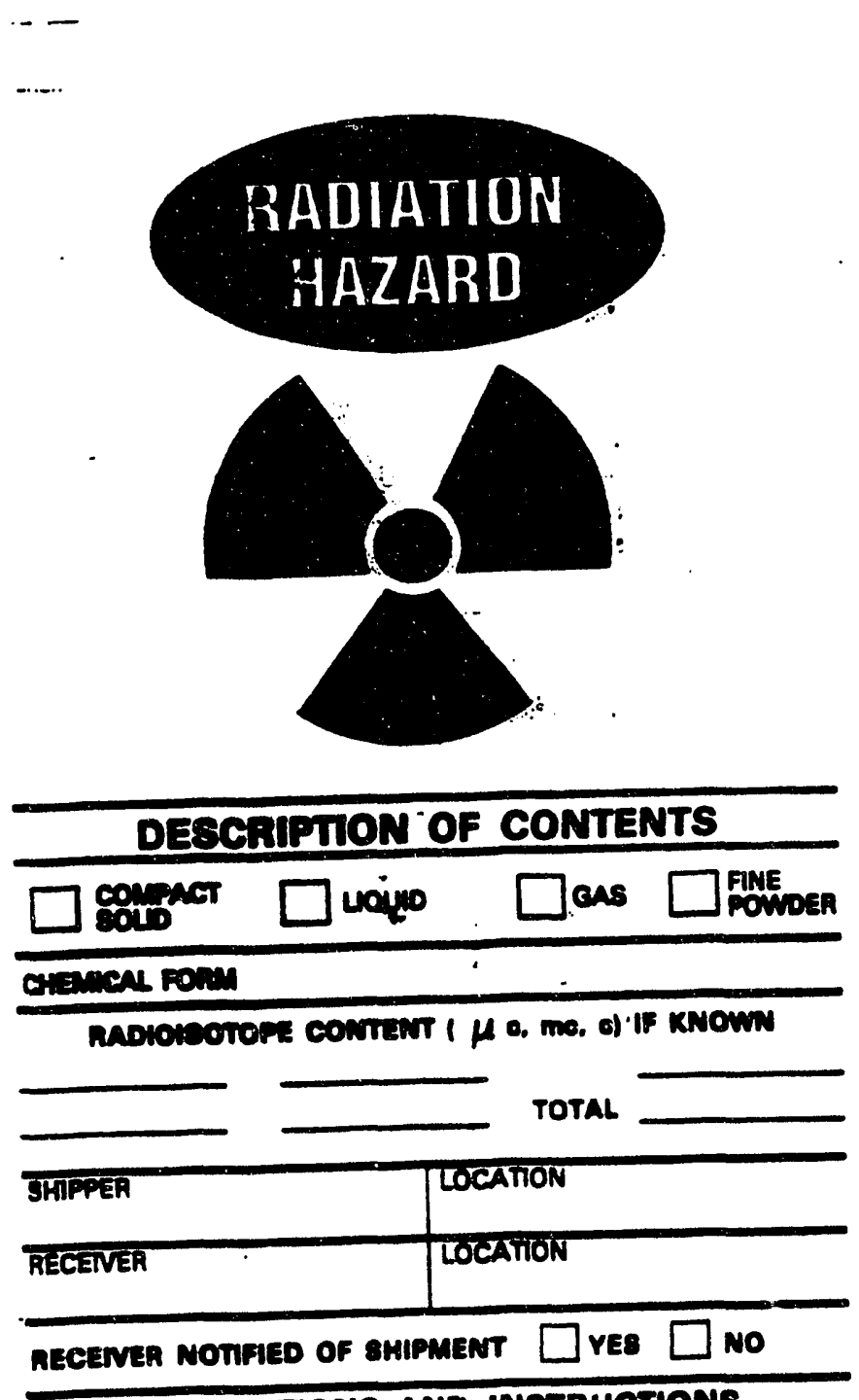

PRECAUTIONS AND INSTRUCTIONS FOR haNDUNG; OPENING. STORACE, OR DIBPOEAL
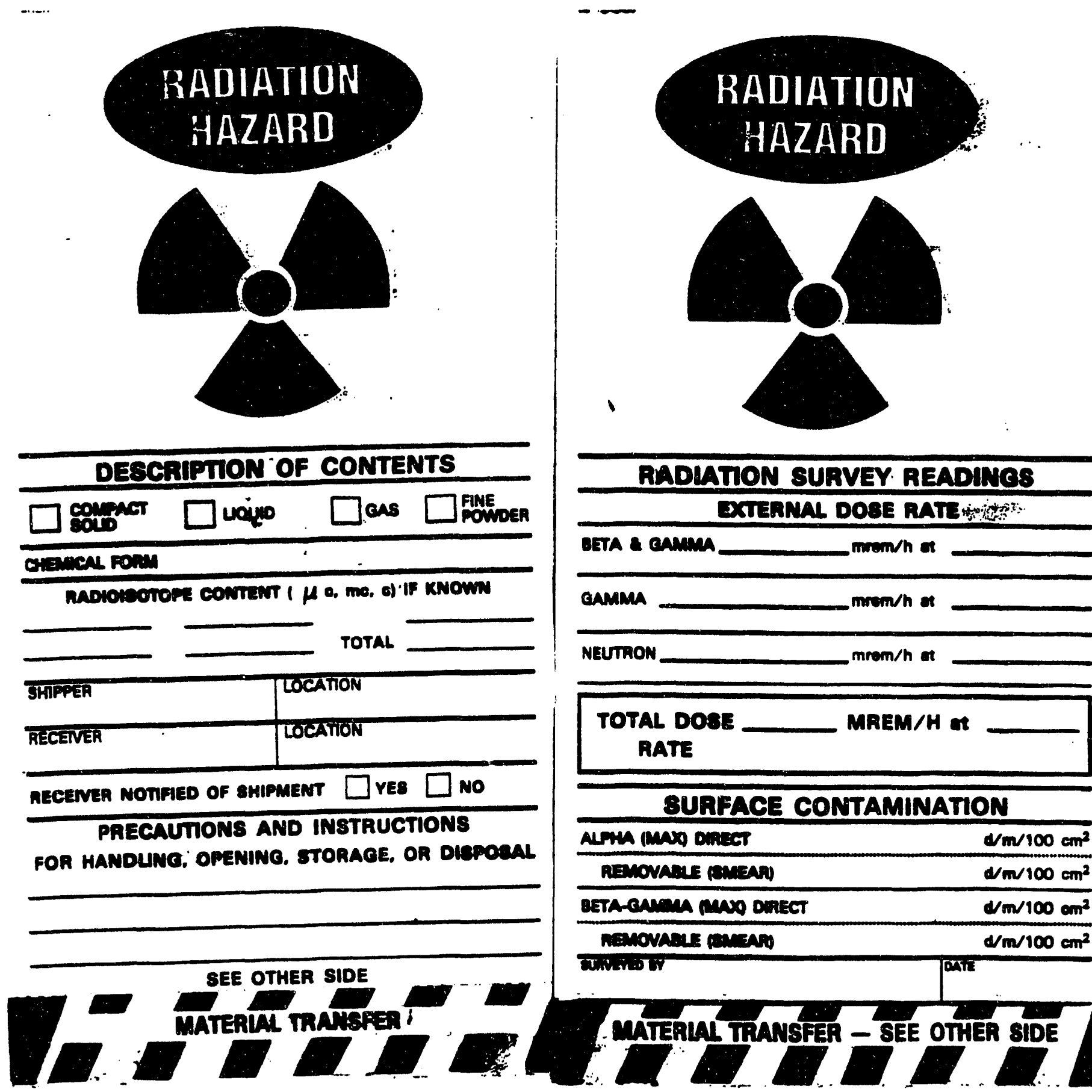

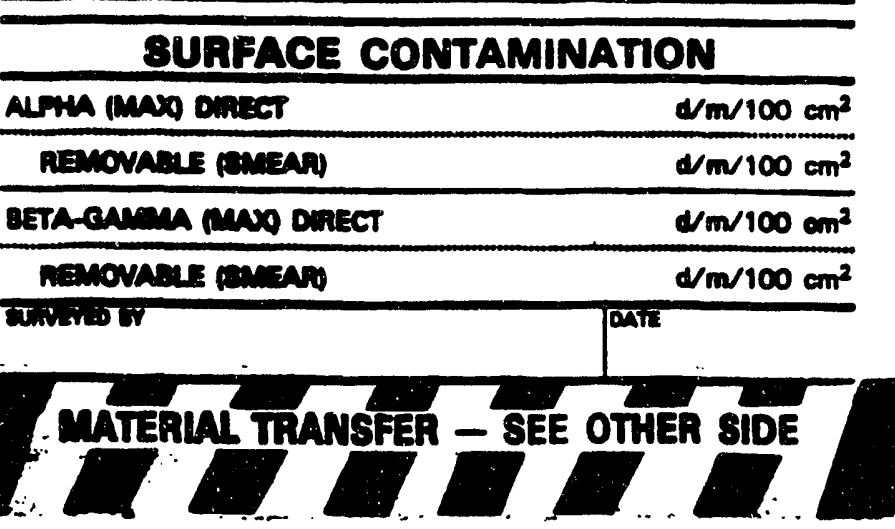




\section{ATTACHMEN'T 4 \\ UCN Form-13075, General Low-Level Radioactive Compactible Waste Tag}


This tag is placed on each SLLW compactible waste bag. Each tag should display the packet number that corresponds to the packet number on the log-in data sheet (UCN-16114).
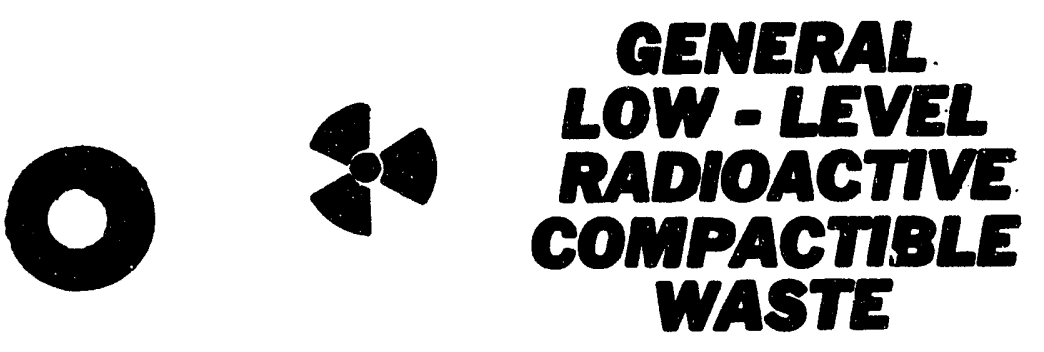

UCN-13075 (3 $1-79)$

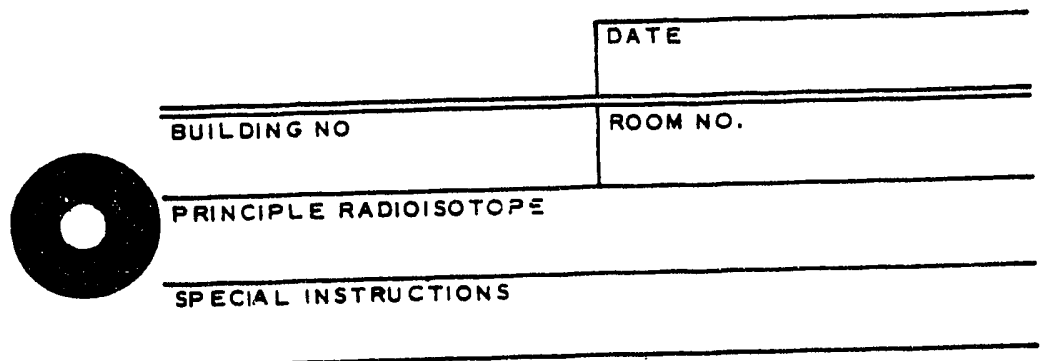

ORIGINATOR: 


\section{ATTACHMEN'T 5}

UCN Form-13698, Request for Disposal of Hazardous and Mixed Waste 


\section{Generator's Instructions For Completing Form UCN-13698 "Request for Disposal of Hazardous and Mixed Waste"}

\section{GENERATOR COMPLETES}

Eorm Comoletion Date - Date form is completed and mailed to the Hazardous Waste Operations Group. (HWOG).

Accumulation Stan Date - Date when hazardous or mixed waste is moved from a satellite accumulation area to a 90-day hazardous waste accumulation area, interim status facility, or a Part B permitted facility; or the date when an excess of 55 gallons of hazardous or mixed waste or one quart of acutely hazardous or mixed waste [40 CFR 261.33(e)] is accumulated in a satellite area. Date when polychlorinated biphenyl (PCB) wastes were first placed in the container.

Page 1 of - - Total number of pages in this submittal. Continuation pages should be numbered sequentially beginning with page 2 .

Waste Generator (Print Name) -- Printed name of person whose act or process produces hazardous or mixed waste.

Buildino/Boom Number - - Generator's building and room number.

Plant - - Plant where generator's work area is located (e.g. QRNL, Y-12, K-25).

Emplovee Number - - Generator's badge number.

Charge/Work Order Number - - Valid charge account so waste quantity and type can be related to generating Division and program. Use of "generar" accounts is distouraged.

Location of Material - - Building or landmark description where waste is located.

Boomor Area - Specific room, dock, or area of waste material bcation.

Ehone Number - - Generator's plant telephone number.

Waste Generator's Signature - - Waste generator signs name. This signature affirms that the information provided is complete and correct.

Item Number - - Item number 1 is preassigned. If a continuation page is needed, on the first continuation page the first item number should be assigned 2 and continued sequentially as needed.

Descriotion of Material - - Be specific. List the chemical abstracts service (CAS) number, if applicable. Only one waste type should be included per item number. If the waste is a mixture, all chemicals and their percentages shall be identified. One item will be included on the first page with up to 10 continuation pages as required for waste from a single waste generation point. If you have more waste than will fit on a set of 11 pages you will need to start a new form. Unknown waste will not be accepted. Analysis of unknown waste shall be performed at the generator's expense prior to waste collection.

Physical Form - Check the physical form. If "other" is marked describe the physical form.

Quantity Net Volume. Units - Estimate the actual volume that the waste occupies in the container. Acceptable units are cubic feet, gallons, millititers, cubic meters, liters, fluid ounces.

Number ol Containers -- Total number of waste packages to be collected.

Comainer Type -- Department of Transportation specitication if applicable (e.g. DOT 17H, DOT 17E, DOT 37A, DOT 17C, DOT 6D). 
Generation Process - - Indicate code listed below for process or type activity that resulted in this waste item:

$\begin{array}{lll}\text { OP } & - & \text { Ongoing process } \\ \text { OM } & - & \text { Ongoing maintenance } \\ \text { EC } & - & \text { Ongoing off-specification or excess chemical } \\ \text { OTP } & - & \text { One time planned } \\ \text { S } & - & \text { Spill or unplanned generation } \\ \text { RA } & - & \text { Remedial activities } \\ \text { O } & - & \text { Other (explain: }\end{array}$

Determination Methed - - How was the RCRA Hazarcous Waste determination made? Indicate code
A - Analytical Results (attach results to UCN-13698 form)
KP - Knowledge of process which generated the waste

EPA Hazardous Waste Number - The number assigned by EPA to each hazardous waste listed in 40 CFA 261 and to each characteristic identified in 40 CFR 261. Include all applicable and appropriate numbers.

Radiologlcal Area - - Was the waste generated in a radiological area as defined in Health Physics Manual Chapter RP-2.3?

Iotal Curies -- Total curies in the waste item.

Badioactive -. Check Yes or No. Determination to be based on ORNL HP Manual Appendix A13.

Isotope(s). Quamity and Unit - - If radioactive, estimate specitiq isotopes, quantity, and corresponding unit.

Special Instnuctions/Precautions for Handling -. If waste is a manufacturer's product, attach a Material Safety Data Sheet (MSDS) for the waste material(s) to UCN-13698 form. List any additional hazards based on your experience with this material.

Indicate if the waste contains naturally occurring or accelerator produced radioactive material (NARM) or special nuclear material (SNM) and if so list the specific isotopes.

HEALTH PHYSICS (HP) COMPLETES

Alpha - - Surface reading on the waste container. Units should be disintegrations per minute (dpm).

Beta-Gamma - - Survey results for beta gamma radiation. Units should be milliren/hour (mrem/hr.).

Rad.Hazards - - List any special instructions or precautions waste handlers should observe.

HP Sunevor's Sianature and Date - - Surveyor signs and dates in the appropriate space at the bottom of the first page.

PLANT \& EQUIPMENT (P\&E) COMPLETES

Transperter's Signature and Date -. Transporter signs and dates in the appropriate space at the bottom of the first page.

IRANSPORTATION OPERATIONS MAMAGEMENT DEPARTMENT (TOMD) COMPLETES

TOMD Review and Date - - TOMD representative signs and Jates the appropriate space at the bottom of the first page indicating review and date of review.

UCN-13898 inmenctions (Beck) 

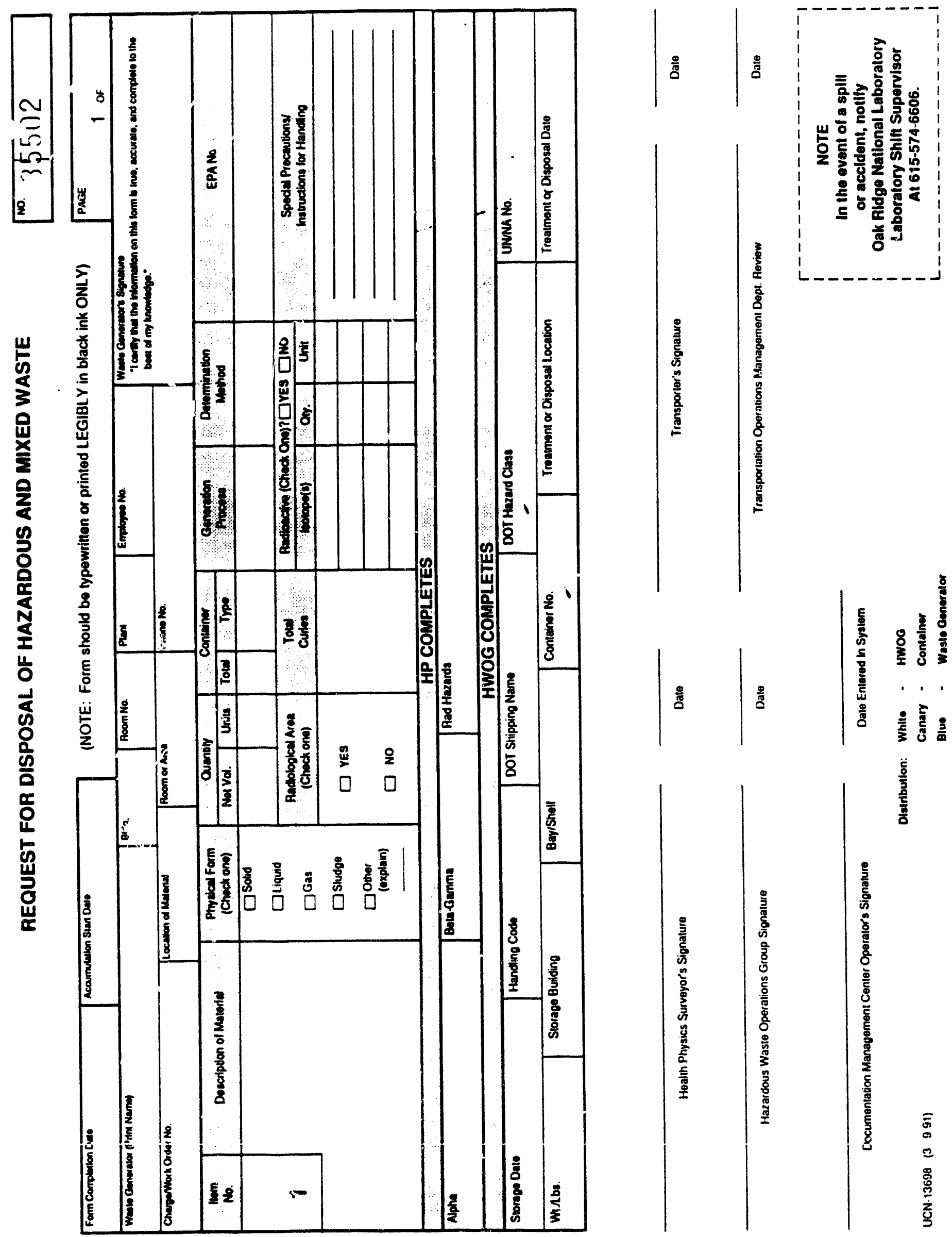


\section{ATTACHMENT 6}

UCN Form-13386, Request for the Disposal of Asbestos or Material Containing Asbestos 


\section{REQUEST FOR THE DISPOSAL OF ASBESTOS OR MATERIAL CONTAINING ASBESTOS}

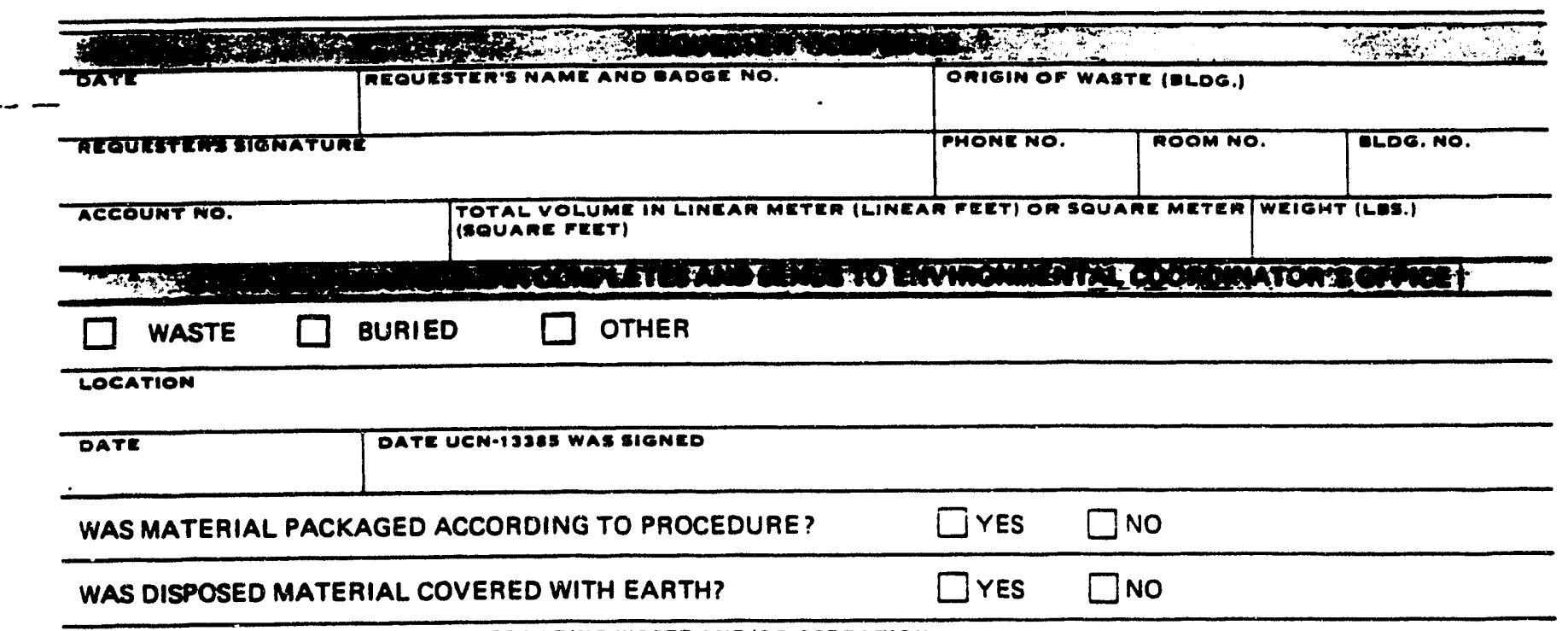

\footnotetext{
COMMENTS FROM SWSA FOREMAN REGARDING WASTE ANDIOR ORERATION
}

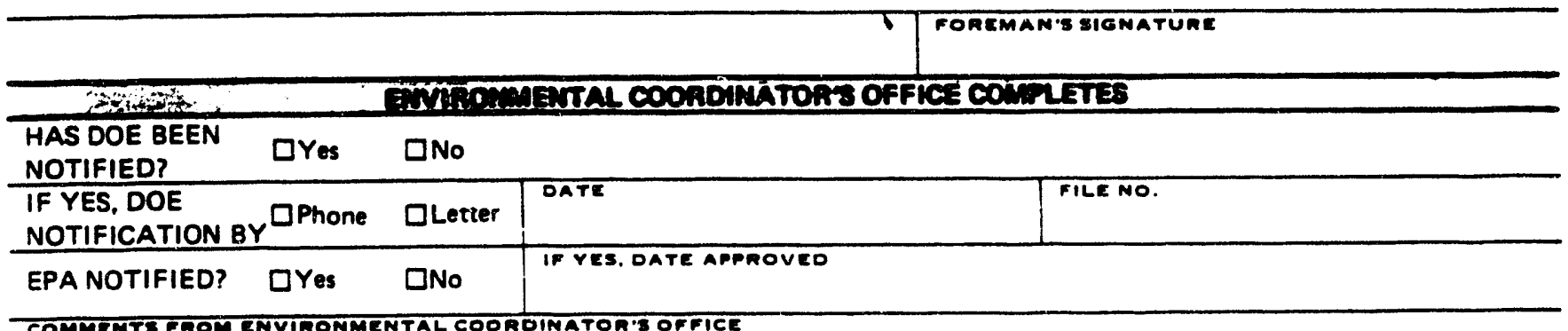

COMMENTE FHOM EAVINONMENTAL COOAOINATOA'B OFFICE 
ATTACHMENT 7

UCN Form-19611, Environmental Restoration

Waste Management Program

Generated Waste Form Summary Report 


\section{WASTE REPORTING REQUIREMENTS FOR ATTACHMENTS 7 AND 8}

This section describes reporting requirements for RA and D\&D projects. Energy Systems is responsible for meeting the reporting requirement for ER WM activities to maintain compliance with applicable Department of Energy orders and its own policies and procedures.

\section{WASTE GENERATION ACTUALS FORM REQUIREMENTS}

The ER waste generation actuals form (Attachment 7) records all project waste requiring handling by the WMO. Information for each waste material type should be put on a separate UCN form. No mixing of information should exist pertaining to material types on any one form. The form is to be submitted weekly to the ORNL ER Program WM Coordinator, unless a wavier has been granted. Data recorded on the form include

- site (ORNL, the Y-12 Plant, the K-25 Site, Paducah Gaseous Diffusion Plant, or Portsmouth Gaseous Diffusion Plant),

- activity generating the waste,

- volume and weight,

- waste material type,

- waste category, and

- chemical contaminants.

\section{WASTE GENERATION FORECAST FORM REQUIREMENTS}

The ER Generation Forecast Data Base is used to communicate future ER management requirements to the offices of WM and ER. The waste forecast identifies total estimated waste volumes for a project, and those specific waste volumes anticipated for removal to TSD facilities outside the AOC. Before undertaking any D\&D, RI, or RA, a waste volume forecast form must be completed and returned to Central ER WM Division, the ORNL ER Program Office, and the Baselining Planning Group. Attachment 8 is a copy of the proposed waste generation forecast form. 


\section{ENVIRONMENTAL RESTORATION WASTE MANAGEMENT PROGRAM} GENERATED WASTE

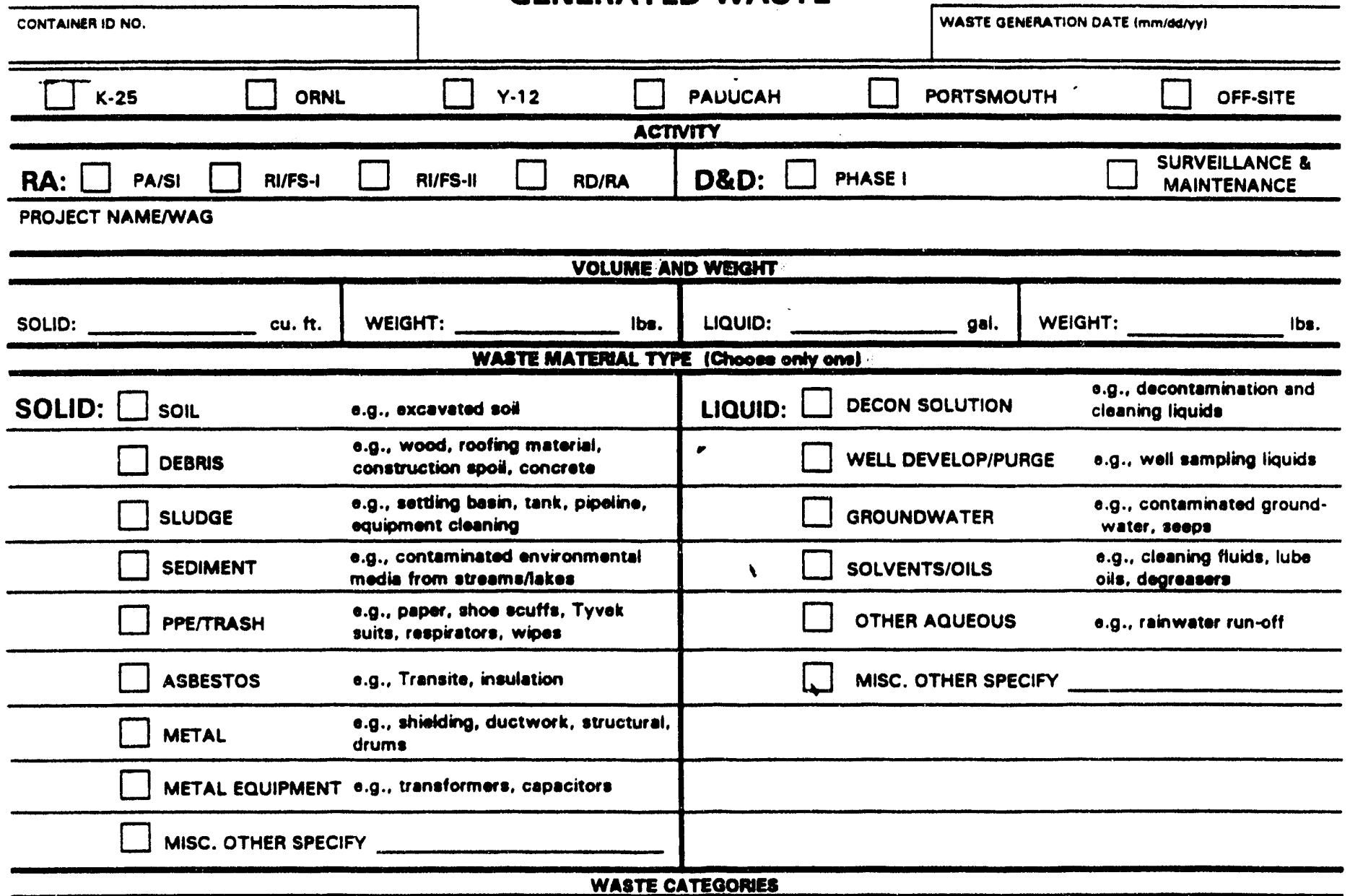

\begin{tabular}{|c|c|c|c|c|}
\hline LLW & TRU & LLW/TSCA & TRU/RCRA & FREE $\cdot \mathrm{Hg}$ \\
\hline RCRA & SANITARY & LLW/RCRA/TSCA & TRUITSCA & \\
\hline TSCA & LLW/RCRA & RCRA/TSCA & TRUILLW & \\
\hline
\end{tabular}

CHEMical CONTAMWANTS lall knownl

\begin{tabular}{|c|c|c|c|c|c|}
\hline 1. CONTAMINANT & CONCENTMATIONUNMTS & $\square$ & $\begin{array}{l}\text { Process Knowledge } \\
\text { Lab Analyaie }\end{array}$ & $\begin{array}{l}\text { Document No. } \\
\text { Document No. }\end{array}$ & \\
\hline 2. CONTAMINANT & CONCENTRATIONMNMTS & $\square$ & $\begin{array}{l}\text { Piocoss Knowledge } \\
\text { Lab Analysie }\end{array}$ & $\begin{array}{l}\text { Document No. } \\
\text { Document No. }\end{array}$ & \\
\hline 3. CONTAMINANT & CONCENTIUTIONUNMTS & $\pi$ & $\begin{array}{l}\text { Process Knowleodge } \\
\text { Lab Analyaia }\end{array}$ & $\begin{array}{l}\text { Document No. } \\
\text { Document No. }\end{array}$ & \\
\hline 4. CONTAMINANT & CONCENTRATIONUNATS & & $\begin{array}{l}\text { Process Knowlodge } \\
\text { Lab Analysis }\end{array}$ & $\begin{array}{l}\text { Document No. } \\
\text { Document No. }\end{array}$ & \\
\hline 5. CONTAMINANT & CONCENTRATIONUNITS & & $\begin{array}{l}\text { Process Knowlodge } \\
\text { Lab Analysie }\end{array}$ & $\begin{array}{l}\text { Document No. } \\
\text { Document No. }\end{array}$ & \\
\hline 6. CONTAMINANT & CONCENTAATIONNUNITS & $\square$ & $\begin{array}{l}\text { Process Knowlodgo } \\
\text { Lab Analysis }\end{array}$ & $\begin{array}{l}\text { Document No. } \\
\text { Document No. }\end{array}$ & \\
\hline 7. CONTAMMINANT & CONCENTRATIONWUNATS & $\square$ & $\begin{array}{l}\text { Process Knowlodge } \\
\text { Lab Anaivais }\end{array}$ & $\begin{array}{l}\text { Document No. } \\
\text { Document No. }\end{array}$ & \\
\hline 8. CONTAMMIMANT & CONCENTMATIONNUNATS & $\square$ & $\begin{array}{l}\text { Process Knowlodge } \\
\text { Lab Analysis }\end{array}$ & $\begin{array}{l}\text { Document No. } \\
\text { Document No. }\end{array}$ & \\
\hline FOren COMPLETEO or inemes & & saoc & oe mumaen & DATE (mm/da/ry) & \\
\hline
\end{tabular}

\begin{tabular}{|c|c|c|c|}
\hline & DAstriturtow: & 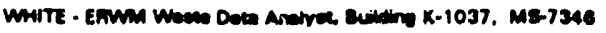 & CANaAT - Fil Copr \\
\hline
\end{tabular}




\section{ATTACHMENT 8 \\ UCN Form-19665, \\ Environmental Restoration Program \\ Waste Generation Forecast}



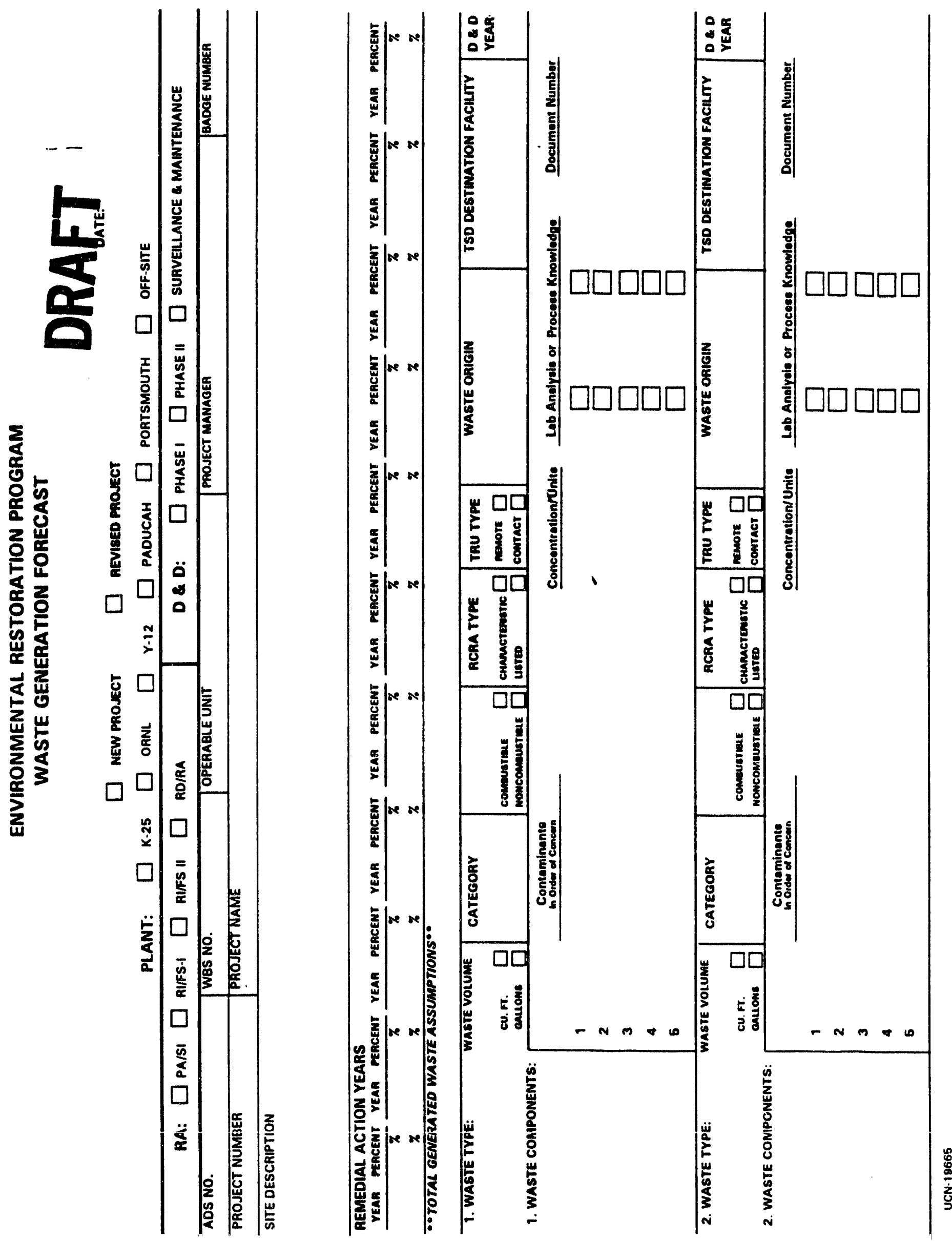


\section{ATTACHMENT 9}

TX-5352 Form, Data Log Sheets for Packaging TRU 


\section{INSTRUCTIONS FOR COMPLETING "THE DATA LOG SHEETS FOR TRU WASTE" (TX-5352)}

\section{REFERENCES}

1. ORNL TRU Waste Certification Document, ORNL/TM-10322.

2 TRU Waste Acceptance Criteria for WIPP, WIPP/DOE-069.

3. Radioactive Solid Waste Operations Manual, WM-HRWO-501.

4. ORNL Environmental Protection Manual.

NOTE: ALl entries requesting signatures must be signed by the person responsible -- initials are not acceptable.

\section{DATA ENTRIES AT THE TOP OF THE PAGE}

Drum ATN - Drum accountability and traceability Number. This number is located on the bar coded label affured to the drum. Do not use drums without a bar code label attached.

Buildine No. - Building number in which the waste was generated.

Room No. - Room number or other information that identifies the specific location, within the building, where the waste drum is located.

Content Code - Check the appropriate block The correct "Cpntent Code" identification can be obtained from the Generator Certification Official, or from the certification document ORNL/TM-10322

\section{DATA COLUMN ENTRIES}

1. Packet Number (Pak No.) - Waste packet number. All waste material placed in the container must be properly bagged or sealed. The first package placed in each container should be labeled number one and each subsequent package should be labeled and numbered sequentially thereafter.

2. Date - The date that the waste material or packet is placed in the container.

3. Radiation Data - Monitor all waste materials/packets placed in the container for radiation emission using Health Physics approved instruments. Record the readings in $\mathrm{mRem} / \mathrm{h}$ in the designated column.

Beta/Gamena - Monitor for beta-gamma radiation using a "Cutie Pie" or a comparable Health Physics approved instrument placed in contact with the waste materialpackage.

Neutrons - Monitor for neutron emissions using a moderated BF3 counter or a comparable Health Physics approved instrument placed in contact with the waste materialpackage.

4. Activity - Enter your best estimate of the total activity of the waste packet in curies. The estimate should be as accurate as possible. 


\section{INSTRUCTIONS FOR COMPLETING THE DATA LOG SHEETS FOR TRU WASTE"}

(IX-5352).

5. Dominant Radionuclides - List the major radionuclides in the waste, in order of their concentration at the time the waste is placed in the drum - starting with the most dominant radionuclide.

6. Physical Form - Briefly describe the physical form of the waste. Acceptable entries include plastic, paper, glass, metal parts, soil, wood, rubber parts, cloth, electrical components, tools, filters, machinery, etc.

7. Chemical Form - Describe the chemical form of the dominant radionuclides. Acceptable eatries include oxide, chloride, nitrate, metal oride, elemental inorganic salt, general chemical description - etc.

8. Percent Combustible (Percent Comb.) - Enter the best estimate for the total amount of combustible content of the waste in terms of percent of total volume of the packet (i.e., $25 \%, 50 \%, 75 \%$, or $100 \%)$.

9. Hazardous Materiais (Haz M(l) - Indicate with a "Yes" or "No" whether the waste packet contains any hazardous materials as described by 40 CFR para 261, and WIPP/DOE-069. If the answer is "Yes", the supplemental log sheet "Data Log Sheet For Packaging TRU Mixed Waste" (TX-5352A) must be completed and attached to the data package for this container.

10. Signature - Signature of the person placing the packet or bagged article in the waste container (INITLALS ARE NOT ACCEPTABLE). This sigmature certifics that the person has successfully completed training course on "Proper Packaging of Transuranic Waste", that the waste has been pacicaged in accordance with the stamdard operating procedure for packaging TRU waste for that facility, and that the waste packet or bagged article placed in the drum contains no free liquids, compressed gas cylinders or other nonconformance item specified in ORNLTM-10322.

11. Data Lor Shcet Verification - Verification must be made, on a routine basis, that the data log sheet is being used properly. For TRU waste this check can be made by the QAR, GCO, or HP representative for the area. The date of the check and the signature of the person making the check must be entered in the appropriate columns (INITIALS ARE NOT ACCEPTABLE). (The person making the verification must have passed the training course on "Proper Packaging of Transuranic Waste").

SIGNATURES AT THE BOTTOM OF THE PAGE (When multiple pages are involved, these signatures are required on the lat page only)

Proper Drum Closure - This signature certifies that the lid has been correctly placed on the drum to obtain a good seal, i.en, the lid gasket has been property seated and the closure ring bolt has been tightened to the correct torque of $45 \mathrm{ft} \mathbf{l b}$.

Generator Certification Official - This signature certifies that the GCO has confirmed that all personnel placing waste in the referenced container have been property trained to package transuranic waste, that the correct forms have been completed and, to the best of his knowledge, that the waste container has been property pactaged in accordance with applicable storage and disposal requirements defined in ORNL/TM-10322

Authorized Radioactive Solid Waste Operations - This signature certifies that the container is in proper condition for transportation according to applicable regulations, and that it meets the requiremeñis for SWSA pickup. 


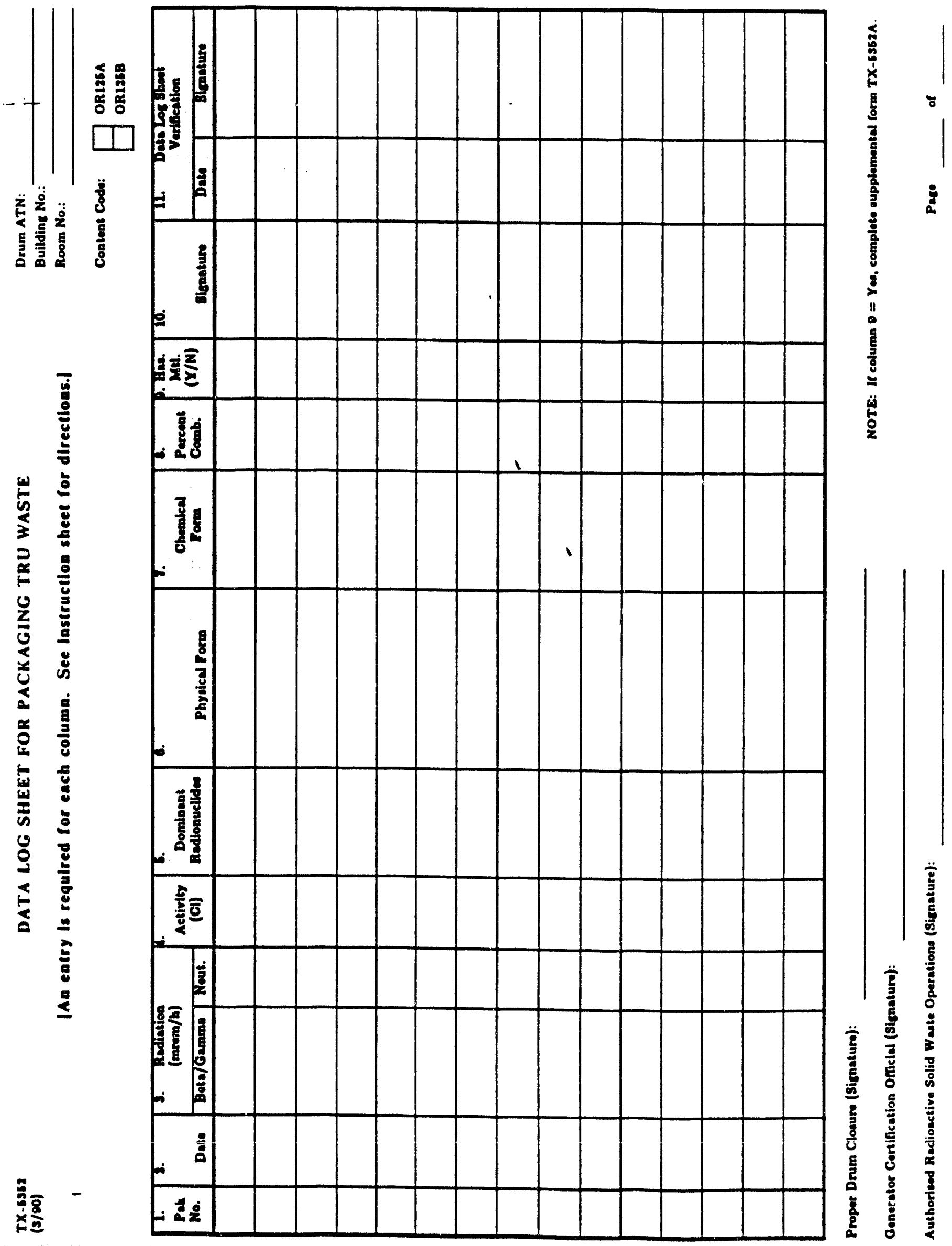


ATTACHMEN'T 10

TX-5352A Form, Data Log Sheets for Packaging

TRU Mixed Waste 


\section{INSTRUCTIONS FOR COMPLETING "THE DATA LOG SHEETS FOR PACKAGING TRU MIXED WASTE" (TX-5352A)}

TRU mixed waste is TRU waste that also contains hazardous materials. Only those hazardous materials that are co-contaminated with TRU radionuclides may be placed in a TRU waste container. The supplemental data log sheet for TRU micred waste is to be completed whenever hazardous materials (defined by 40CFR 261 and WIPP/DOE-069) are placed in the waste container. This will be indieated by a "Yes" entry in column 9 of the primary data log sheet for the TRU waste packet. Both log sheets are required for TRU mixed waste.

NOTE: AIL entries requesting signatures must be signed by the person responsible initials are not acceptable.

\section{DATA ENIRIES AT THE TOP OF THE PAGE}

Drum ATN - Drum accountability and traceability Number. This number is located on the bar coded label affixed to the drum. Do not use drum without a bar code label attached.

Building No. - Building number in which the waste was generated.

I

Room No. - Room number or other information that identifies the specific location, within the building, where the waste drum is located.

Content Code - Check the appropriate block The correct "Content Code" identification can be obtained from the Generator Certification Official, or from the certification document

ORNLTM-10322

\section{DATA COLUMN ENTRIES}

1. Packet Number (Pak No.) - Waste packet number. All waste material placed in the container must be properly bagged or sealed. The packet number should be the same as that used on Form TX-5352.

2 Date - The date that the waste material or packet is placed in the container.

3. Description of Hazardous Material - Describe the physical characteristics of the hazardous material contained in the waste packet. Examples are: silver plated electrodes, cadmium coated samples, lead brick, lead pigs, lead sheet, leaded rubber gloves, solvent contaminated wipes, mercury vapor lamps, mercury thermometer, etc.

4. Hazardous Determination (Haz Det) - Indicate the method used to determine that the waste is hazardous. If the determination was made by analytical testing, mark an " $A$ " in the column. If the determination was made based on the generator's knowledge of the process mark an "B" in the column.

$$
\begin{aligned}
& \text { A - Analytical Testing } \\
& \text { B - Basic Process Knowledge }
\end{aligned}
$$

5. Quantity - Enter your best estimate of the total amount of hazardous material in the waste packel. The entry should be made in terms of weight and volume including dimensions.

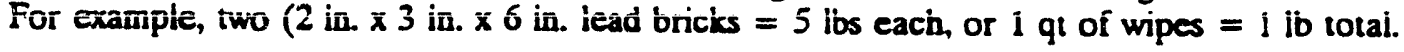


6. Hazard Information - Describe the bazardous characteristics of the waste. Preferred descriptions are: Corrosive, Reactive, Ignitable, and EP toxic (for heavy metals such as leach, mercury, silver, etc.). Other identifies can be: Dioxins, Listed Spent Solvents (i.e. acetone, trichloroethylene, methylene chloride, etc.), and Listed Chemical Products (provide actual chemical name, such as formic acid, lead acetate, etc.). For information on how to identify hazardous wastes, or how to identify the hazardous characteristies of RCRA materials, refer to 40 CFR, Page 261, Subparts A,B,C, and D. Questions concerning this entry should be directed to your supervisor or Generator Certification Official

7. RA Waste Jumber - If the material is a hacardous waste, as defined by RCRA regulations, then an EPA waste number must be provided. Lists of hazardous wastes and their aseociated EPA waste numbers can be found in 40 CFR, Part 261, Subpart D. If the waste is not listed in Subpart D, but is exhibits one of the RCRA defined characteristics of a hazardous waste, the waste will be given the following EPA numbers corresponding to the hazardous characteristic:

\begin{tabular}{ll} 
Characteristic & EPA Number \\
\hline Ignitable & DOO1 \\
Corrosive & $\mathrm{DOO2}$ \\
Reactive & $\mathrm{DOO3}$ \\
EP Toxic & See Table 1, Subpart C
\end{tabular}

Questions concerning this entry should be directed to your supervisor or GCO.

8. S mature - Signature of the person placing the packet or bagged article in the waste container (INITIALS ARE NOT ACCEITABLE). This signature certifies that the person has successfully completed training course on "Proper Packaging of Transuranic Waste", that the waste has been packaged in accordance with the standard operating procedure for packaging TRU waste for that facility, and that the waste packet or bagged article placed in the drum contains no free liquids, compressed gas cylinders or other nonconformance item specified in ORNL/TM-10322.

9. Data Log Sheet Verification - Verification must be made, on a routine basis, that the data log sheet is being used property. For TRU waste, this check can be made by the QAR, GCO, or HP representative for the area. The date of the check and the signature of the person making the check must be entered in the appropriate columns (INITIALS ARE NOT ACCEPTABLE). (The person making the verification must have passed the training course on "Proper Packaging of Transuranic Waste").

SIGNATURE AT THE BOTTOM OF THE PAGE (When multiple pages are involved, this signature is required on the lest page only)

Generator Certification Official - This signature certifies that the GCO has confirmed that all personnel placing waste in the referenced container have been properly trained to package transuranic waste, that the correct forms bave been completed and, to the best of his knowledge, that the waste container has been properly packaged in accordance with applicable storage and disposal requirements defined in ORNL/TM-10322. 


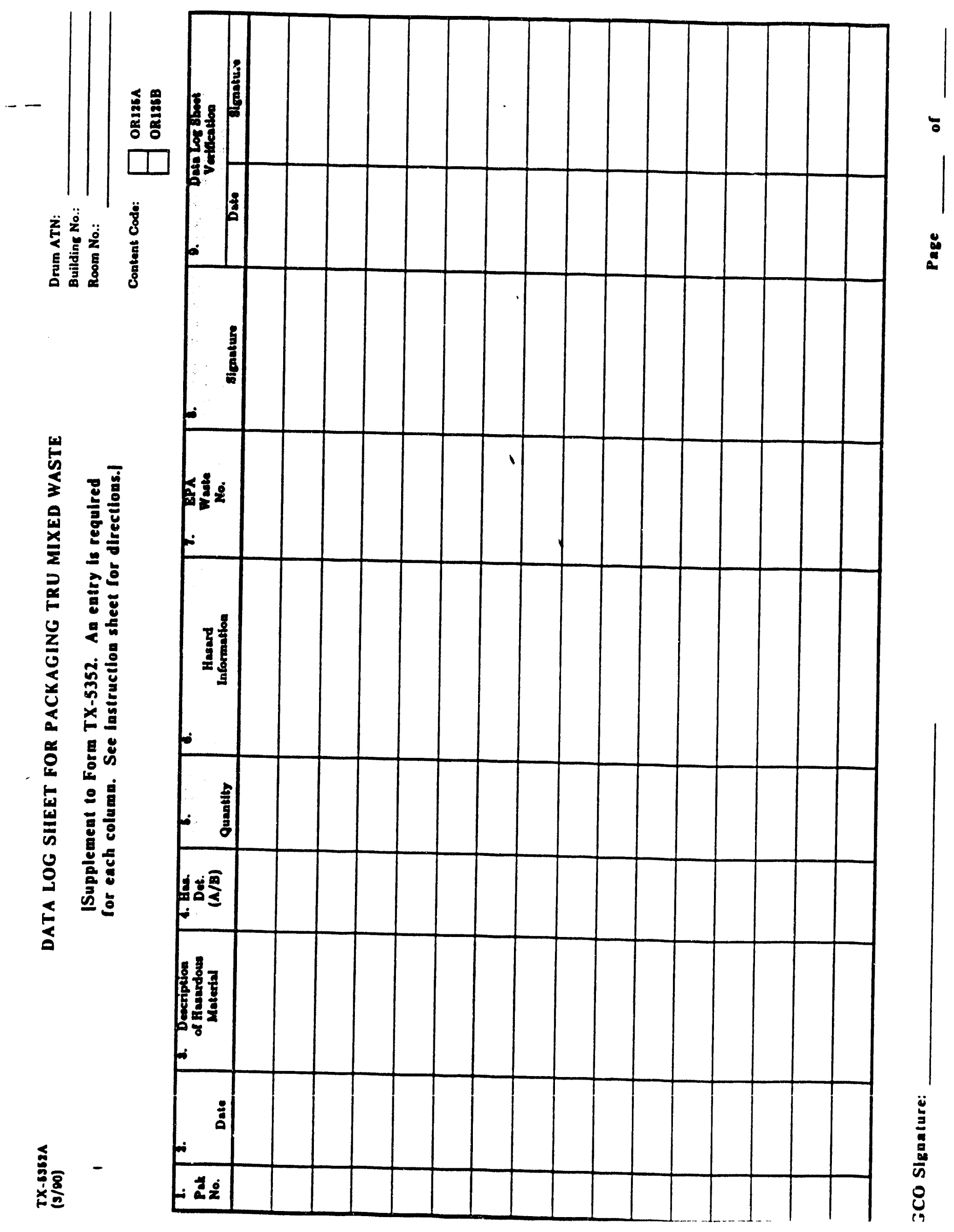




\section{ATTACHMENT 11}

UCN Form-2109, Request for Transfer, Storage, or Disposal of Waste 


\section{UCN-2109 INSTRUCTIONS}

1. Description of Materials: Be specific. List similar material types on the same UCN-2109. Similarity is determined by form (solid, liquid, gas, sludge). Type (metal, glass, wood, oil, coolant, organic, solvent, aqueous solutions, etc) and contaminants (uranium, beryllium, thorium, PCB, mercury, etc.) Limit each disposal request to a single waste form, type, and contaminant per UCN-2109. Contact the Plant Disposal Coordinator (6-7897) to minimize the papenwork requirements.

2 Check appropriate block.

3. Is waste classified? Check the appropriate block. If unsure, contact the Division Classification Representative.

47. Check yes or no for each.

8 Does waste contain carcinogen? Check the appropriate block. If yes, indicate chemical name.

2 Is waste radioactive? Check the appropriate block. If yes, give the assay, if known, and list all other radioisotopes that may be present. (Ex. Pu239, Cs137)

10. List contaminants not identified in $\# 4$ through $\# 9$.

11. Is material RCRA waste? Check the appropriate block.I Identify either a hazardous or non-hazardous waste, as defined by the Resource Conservation and Recovery Act (RCRA). Give the correct EPA hazardous waste code listed in the regulation, in addition to the accumulation start date. If unknown, contact Division Environmental Officer for assistance. (See Hem 25.)

12 Hazards in Handling: Indicate possible hazards based upon your experience with the material. Also, indicate respirator requirements.

13. Container Type: List container type by recording the DOT container specification, if known. Complete and attach a copy of a UCN-2114 (Tag) to each waste container.

14. Indicate blue, green, brown, or yellow tag.

15. Show the container count.

16. Net Volume of Waste: Indicate the net waste volume in cubic feet or gallons. Do not include the volumes of the containers.

17. Gross Weight of Containers: Indicate the gross weight of the waste in pounds.

18. Waste Location: Indicate where the material is located. The waste must be moved to a loading dock or other accessible location.

2 Use the division charge number designated for waste disposal.

19-24. Required Signatures: Each UCN-2109 form shall be signed by the Waste Generator. Division Environmental Officer, and the Representative Derivative Classifier. Contact your division Department Head office for a list of those authorized to sign this form.

Waste Generator - Must sign certifying that the wasie has been properly characterized.

Division Environmental Officer - Must sign and determine that the proper information is given.

Division Classification Representative - Must sign and is responsible for verifying that the proper information is given in item \#3. 


\section{REQUEST FOR TRANSFER, STORAGE, OR DISPOSAL OF WASTES (No Classified information Should Be Emtered When Using This Form.)}

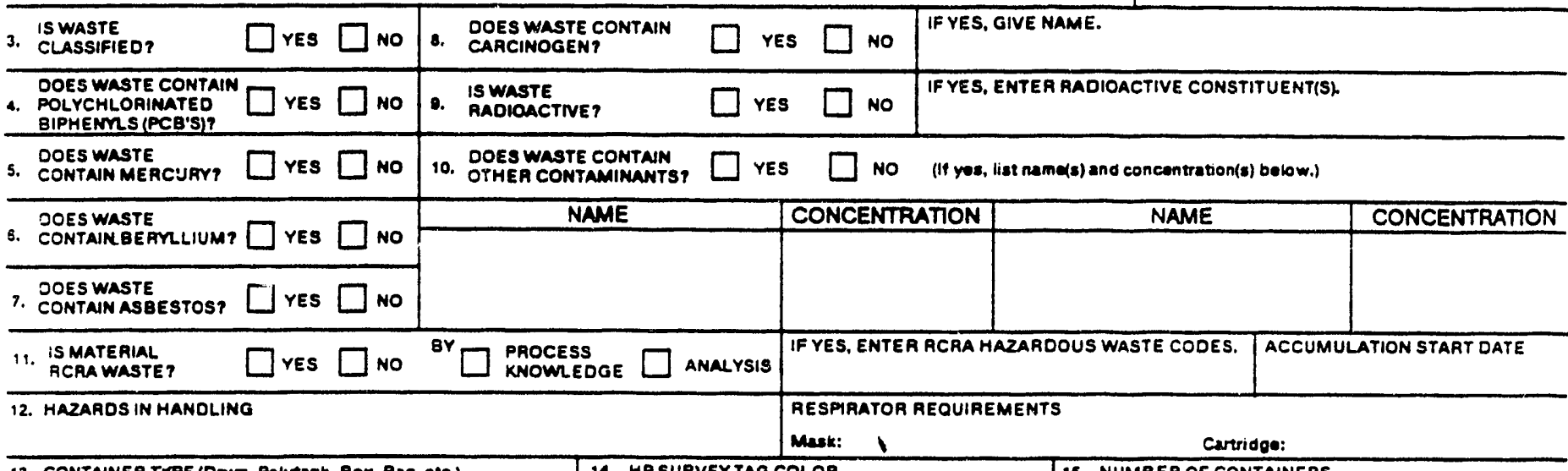

13. CONTANEA TYPE (Drum, Polytank, Box, Bag, ota)

14. HP SUAVEYTAG COLOR

15. NUMBER OF CONTAINERS

\begin{tabular}{|l|l|l|l|l|}
\hline 16. NET VOLUME OF WASTE & VOL. UNITS (Cubic Feat or GalionS) & 17. GROSS WEIGHT OF CONTAINERS & WEIGMT UNITS \\
\hline
\end{tabular}

18. WASTE LOCATION

Building:

Dock of Pickup Area:

\begin{tabular}{|l|l|l|l|}
\hline 19. WASTE GENERATOA NAME (PTint) & 20. PHONE NO. & 21. BUILDING/MAIL STOP & 22. CHAAGE NO. \\
\hline
\end{tabular}

\begin{tabular}{c|c|l|l|l|}
\hline $\begin{array}{c}\text { 33. WASTE GENERATOR } \\
\text { SIGNATURE }\end{array}$ & $\begin{array}{c}\text { I CERTIFY THAT THE ABOVE INFORMATION } \\
\text { IS COMPLETE AND CORRECT. }\end{array}$ & SIGNATUAE & DATE \\
\hline
\end{tabular} \begin{tabular}{l|l|l|l|l|l|}
\hline 24. ENVIRONMENTAL OFFICER SIGNATURE & OATE & 25. DERIVATIVE CLASSIFIEA SIGNATUAE & OATE & 26NVIRONMENTAL OFFICER DIVISION
\end{tabular}

\begin{tabular}{|c|c|c|c|c|c|}
\hline 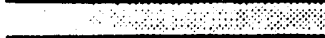 & & \\
\hline 27. TECHNICAL CONTACT & \multicolumn{4}{|c|}{$\begin{array}{l}\text { INFOAMATION BELOW TO BE COMPLETED BY WASTE MANAGEMENT } \\
\begin{array}{|l|l|l|}\text { DATE ASSIGNED } & \text { 28. PAOPE A DOT SHIPPING NAME }\end{array}\end{array}$} & \\
\hline 29. HAZARD CLASSIFICATION & \multicolumn{2}{|c|}{ 30. UN OR NA NUMBER } & & 31. FIELD REVIEW SIGNATUAE & DATE \\
\hline 32. SAMPLE REOUISITION NO. & & DATE & & SAMPLII & \\
\hline
\end{tabular}

33. DISPOSAL INSTRUCTIONS

34. SPECIAL PROTECTIVE EOUIPMENT REOUIRE D (Safoty Glesees and Gloves to be wom as minimum.)

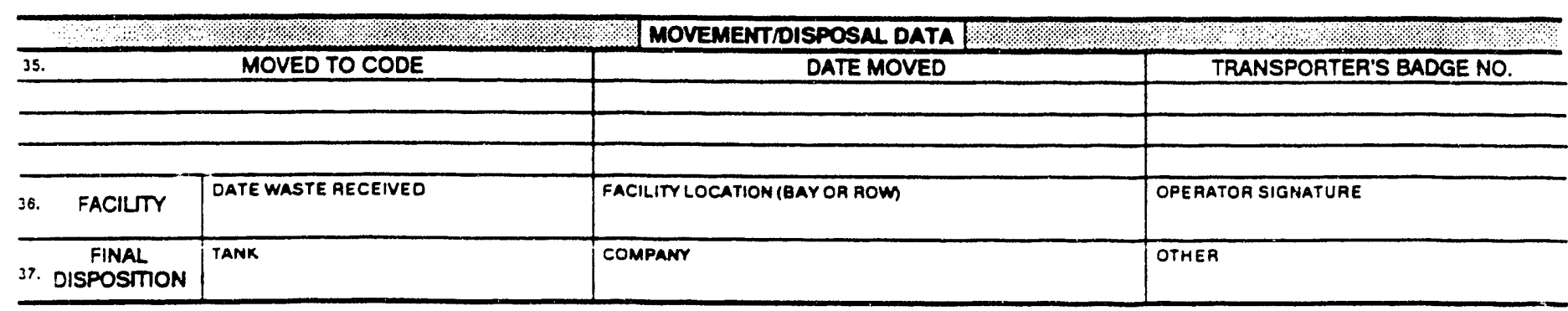




\section{Appendix D \\ The Proposed Energy Systems Uniform \\ Waste Request Sheets for Waste Transfer \\ from Generators to Waste Operations \\ (ORNL, Y-12 Plant, K-25 Site)}

[These proposed forms will be implemented for use beginning fall 1993. The WMO will implement training sessions to instruct generators on the use of the new forms. The training sessions will begin in August 1993. Contact Vicky A. Long (241-2805) in the WM and RA Training Department for scheduling.] 
MARTIN MARIETta

WASTE ITEM CONTINUATION

(Continuation Page 2 of 2 )

\begin{tabular}{|c|c|c|}
\hline \multirow{2}{*}{$\begin{array}{r}\text { Sequerce } \\
\text { Number } \\
1\end{array}$} & \multicolumn{2}{|c|}{ Referenced from WDD (TX-5745) } \\
\hline & II. K'aste ltew ID Number & C1. Container ID. No. \\
\hline
\end{tabular}

\section{CHEAICAL WASTE}

\begin{tabular}{|l|l|l|}
\hline M11. Substance ID & M12. Vol \% & \\
\hline & & \\
\hline & & \\
\hline & & \\
\hline & & \\
\hline & & \\
\hline & & \\
\hline & & \\
\hline & & \\
\hline & & \\
\hline & & \\
\hline & & \\
\hline & & \\
\hline & & \\
\hline
\end{tabular}

RADIOACTIVE WASTE

RADIOACTIVE WASTE
\begin{tabular}{|l|l|l|l|l|l|l|l|l|}
\hline R7. Isotope & R8. Est. Qty & R9. Units & R7. Isotope & R8. Est. Qty & R9. Units & R7. Lotope & R8. Est. Qty & R9. Units \\
\hline & & & & & & & & \\
\hline & & & & & & & & \\
\hline & & & & & & & & \\
\hline
\end{tabular}




\section{Waste Item Description (TX-5745) Form User Instructions}

PURPOSE: The Waste Item Description (WID) form lists the identity and the chancieristics of a waste item, the smallest trackeble unit of waste. It also lists the identity of the shipping/storage container into which the waste item may have been placed, and any applicable handling information. All of the information on the form is requirod in order to register the waste item with the site waste management organization, however some of the information is only applicable to specific unste calcgories.

\section{WASTE ITEM IDENTIFICATION}

Form ID Numbernaste llem Barcode Label (upper right comer):

If waste item barcode labels are used, each waste item is identified by attaching the pre-printed waste item ID barcode label to it. A duplicate barcode label is attached to the WD form that describes the waste item in the rectangular box bocated in the upper right comer of the form. If waste item barcode labels are nol used, the WID form is identified by the pre-printed Form ID Number.

11. Waste Item ID Number (Compulsory)

If waste item barcode labels are used, copy the ID number of the waste item from the barcode label atuached to the waste item. If waste item barcode labels are not used, each waste item is identified with a sequence number beginning with sequence number 1.

Exumple: X1019300001

12. Generalor's Name (Compulsory)

PRINT the name of the individual responsible for the generation of the waste item.

13. Badge No. (Compulsory)

The badge number of the waste generator.

Example: 99999

14. Generator's Phone No. (Compulsory)

The complete phone number where the waste generator can be reached.

Example: (615) 576-9999

15. MS (Compulsory)

The mail stop of the waste generator.

Format: 9999

16. Charge Number/wo (Compulsory)

A valid charge account or wort order number for waste handling charges.

Format: A9999AAA or 9999-9999

17. Origin Div. (Compulsory)

The numerical division code of the generating division.

Example: 27

18. Origin Date (Compulsory)

The dale that the waste item was generated or declared waste.

Example: 4/1/93

19. Origin Site (Compulsory)

The site (plant) where the waste was generated.

Examples: X10, Y12, K2S

110. Origin Facility (Compulsory)

The facility (building) where the waste was generated.

Exımple: $4500 \mathrm{~N}$

111. Origin Room/Ares (Compulsory)

The room or area where the waste was generated.

Example: 125L 
112. Radiological Area? (Compulsory)

Is the Origin Room Area $(110)$ a radiological ares (yes or no)?

113. Est. Na Volume (Compulsory)

The estimated net volume of the waste item.

Format: number

114. Vol. Units (Compulsory)

The estimated na volume units.

Values: CUIN, CUFT, CUYD, CC, M3, OZ, PT, QT, GAL, ML, L

115. Est. Gross Weight (Compulsory)

The estimated gross weight of the waste item.

Format: number

116. Wr. Units (Compulsory)

The estimated net weight units.

Velues: OZ, LB, TON, MG, G, KO

\section{CONTAINER INFORMATION}

If the waste item is placed in a standard shipping/storage container, the container will have it's own unique container tD barcode label attached to it. 'Standard' containers are large well defined containers (typically grealer than five gallons). The container ID number on the container barcode label is independent of the waste item ID number on the waste item barcode label.

If the waste item does not require a container or is placed in a non-standard container (glass boules, bags, vials, ac.) it is considered 'self-contsined', in which case there will not be a separate container ID number.

If the waste generation process creates arge quantity of waste which is placed into multiple standard containern, a separate Waste ltem Description will need to be completed for each container.

Waste generation activities often include the accumulation of wasle in a location different from the generation location. When this is the case, the accumulation location is referrod to as the 'holding' location. Complete the holding location information if spplicable.

C1. Conlainer ID Number (Compulsory)

The unique ID number of the standard shipping/storage conlainer for this waste item copied from the container barcode label. If the waste is placed in a non-standard container (glass boute, vial, bag. ac.) or is self-contained enter 'NA'.

Example: X10C9300123

C2. Container Type (Compulsory)

The contuinet type code of the outer container of the waste item. If the contuiner type is not a listed 'standard container' (large well, defined containers), use the most detajed 'generic' container type available in the following list (i.e. DRUM). If there is no suitable container type cade or the waste item is self-contained, enter 'SELF' and provide any additional detailed packaging information in the WASTE DESCRIPTION.

Refer to the following page. 


\section{CONTAINER TYPE LIST}

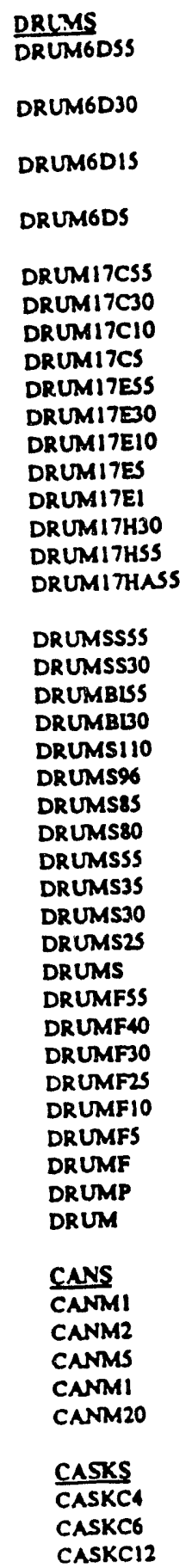

Descripion
Drum, DOT 6D, Sicel.
Poly-lined, S5 8u

Drum, DOT 6D, steel.

Poly-lined, $30 \mathrm{gal}$

Drum, DOT 6D, steel,

Poly-lined, 15 gal

Drum, DOT 6D, sieel,

Poly-lined, 5 gal

Drum, DOT i7C, Steel, ss gal

Drum. DOT 17C, Steel, $30 \mathrm{ge}$

Drum, DOT 17C, Steel, 10 gal

Drum, Dor 17C, Steel, 5 gal

Drum, DOT I7E, Steel, 55 gal

Drum, DOT 17E, Steel, 30 gal

Drum, DOT ITE, Steel, $10 \mathrm{gd}$

Drum, DOT I7E, Steel, 5 gal

Drum, DOT ITE, Steel, 1 gal

Drum, DOT 17H, Steel, 30 gal

Drum, DOT 17H, Sleel, SS gal

Drum, DOT 17H-A, Suinjese

steel, 55 gal

Drum, Stainjess Steel, 55 gd

Drum, Suinjess Steel, $30 \mathrm{gal}$

Drum, Bleck Lron, 55 gal

Drum, Bleck Ison, $30 \mathrm{gal}$

Drum, Steel, $110 \mathrm{gal}$

Drum. Steel, 96 gal

Drum, Steel, 85 gal

Drum, Steel, 80 gal

Drum, Steel, 55 gal

Drum. Sleel, 35 gal

Drum, Steel, $30 \mathrm{gal}$

Drum, steel, 25 gal

Drum, Steel

Drum, Fiber, $55 \mathrm{gal}$

Drum, Fiber, $40 \mathrm{gal}$

Drum, Fiber, 30 gal

Drum. Fiber, 25 gal

Drum, Fiber, 10 gal

Drum, Fiber, 5 gal

Drum, Fiber

Drum, Polyethylene

Drum (generic)

\section{Description}

Can, Metal, 1 gal

Can, Metal, 2 gal

Can, Metal, 5 gal

Can. Metal, $10 \mathrm{gal}$

Can, Meral, 20 gal

\section{Description}

Cask, Concrete, 4.5" wall

Cask, Concrele, $6^{\circ}$ wall

Cask, Concrete, $12^{\circ}$ wall
BQXES

$80 \times 825$

BOX8X8

BOX4X4

BOXM

BOXW

BOX F

Box

TANKS

TANKP600

TANKP330

TANKP

TANKM

TANK

PLATPSTERS

DUMPSTER

ROLLBDN

TRUCKS

COMPTRUCK

DUMPTRUCK

TANKER

TRUCK

MASCELLANEOUS
GICAN
BAGPOLY
CARBOY
LEADCAR
CYLDNDER
SELF

Descriotion

Box, B-25, Metul

Box, Melal, $8 \times 8 \times 20 \mathrm{foc}$

Box, Melal, 4x4x6 foet

Box, Meul

Box, Wood

Box, Fibertand

Box (eeneric)

Description

Tuak, Polyetbylene, $600 \mathrm{gal}$

Tank, Polyechylene, 330 gal

Tank, Polyethylene

Tenk. Metal

Tunk (generic)

Description

Dumpater, Steel

Roll bin

Description

Compactor truck

Dump truek

Tanker truck

Truck (generic)

Description:

Gi Can, 5 gal

Bag, Polyechylene, 4 mil

Carboy

Lead ahielded carrier

Gas cylinder

Self-contuined 
C3. Holding Sile (Compulsory)

The site (plant) where the waste itern/conksiner was held during wasle secumulation. If the waste was not held in a bcation during accumulation different from the generation location enter ' $N A$ ' and omit Holding Facility (CA) and Holding Room/ Area (CS).

Examples: X10, Y12, K2S

C4. Holding Facility (Conditional)

The facility (building) where the waste item/container was held during waste accumulation.

Example: 4500N

CS. Holding Room/Area (Conditional)

The room/area identifier where the waste item/conlainer was held during waste accumulation.

Example: $125 \mathrm{~L}$

\section{WASTE CATEGORY}

W1. Process Stream ID (Compulsory)

The identifier code of a registered process waste stream. If unknown enter "UNK".

W2. Process Catcegry (Compulsory)

The generation process category code of the process or activity which generated this waste. Select the one that best describes the process calegory.

\begin{tabular}{ll} 
& \multicolumn{1}{c}{ Values: } \\
ABT - Abatement & PRO - Process/production (ongoing) \\
CON - Construction/Demolition & RND - Research and development \\
DND - DecommissionDecontamination & REM - Remediation \\
EXC - Excess/oust-of-spec material (ongoing) & TRE - Treatunent \\
MNT - Maintenance (ongoing) & UNP - One-time, unplanned (eg, spill) \\
OTP - Onetime, planned & UNK - Unknown
\end{tabular}

W3. Process Activity (Compulsory)

The generation process activity code of the process or activity which genernted this waste. Select the one that beat describes the process activity from the following calegories. When 'OTHER' is selected for any of the calegories, provide a brief description of the process activity in the WASTE DESCRIPTION field.

\section{PRQCESS ACTIVITY CODES}

\author{
CLEAYTNG AND DEGREASTNG \\ AOI - STRIPPDG \\ AO2 - ACD CLEANDNG \\ AO3 - CAUSTTC (ALKALD) CLEANDNG \\ AOA - FLUSH RDSENG \\ AOS - DIP RDNSDNO \\ AOS - SPRAY RDNSDNG \\ A07 - VAPOR DEGREASING \\ AO8 - PHYSICAL SCRAPDG AND REMOVAL \\ AO9 - CLEAN OUT PROCESS EOUIPMENT \\ A19 - OTHER CLEANDG AND DEGREASING

\section{SURFACE PREPARATION AND FINISHING} \\ AII - PADNTINO \\ A22 - ELECTROPLATTNG \\ A23 - ELECTROLESS PLATING \\ A24 - PHOSPHATING \\ A2S - HEAT TREATING \\ A26 - PICKOING \\ N27 - ETCHDO \\ A29 - OTHER SURFACE COATING/PREPARATION \\ (SPECUFY DN COMOMENTS)
}

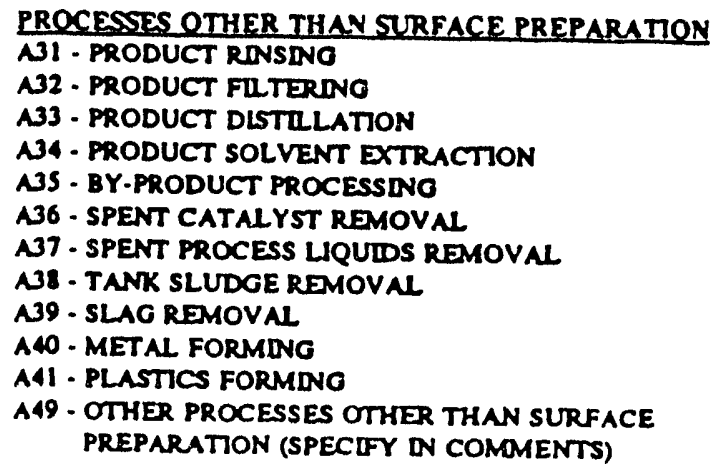


ONETHE AND INTERMTTIENT PROCESSS

ASI - LEAK COLLECTION

N2 - LEACHATE COLLECTION

N3 - CLEANUP OF SPLL RESTUES

NSA - OL CHANGES

ASS - FLT TERBATTERY REPLACEMENT

AS6 - DLSCONTWNUE USE OF PROCESS EQUIPMENT

AS7 - DISCARDNG OFF-SPEC MATERUL

ASE - DISCARDDG OUT-OF.DATE PRODUCTS OR

CHEMICALS

AS9 - LABORATORY WASTES

AGO - SLUDGE REMOVAL

A61 - CLOSURE OF WASTE OR DNTERMTTTENT PROCESSES

(SPECIT DN COMMENTS)

POLLUTION CONTROL OR WASTE TREATMENT PROCESSES

A71 - FULTERNG/SCREENING

A72 - METALS RECOVERY

A73 - SOLVENTS RECOVERY

A74 - DCDNERATION/THERMAL TREATMENT

ATS - WASTEWATER TREATMENT

A76 - SLUDGE DEWATERNG

AT - STABRIZATION

A78 - ARR POLLUTION CONTROL DEVICES

A79 - OTHER POLLUTION CONTROL OR WASTE TREATMENT (SPECIFY D COMOMENTS)

\section{OTIIER PROCESSES}

A81 - CLOTHWNG AND PERSONAL PROTECTIVE EQUTPMENT

A82 - ROUTWNE CLEAN-UP WASTES (E.G., FLOOR SWEEPDNGS)

A89 - OTHER (SPECIFY DN COMONENTS)

W4. Physical Form (Compulsory)

The physical form of the waste. (Select one)

Values: SOLID, LIQUID, GAS, SLUDGE, SLURRY, EMULSION

ws. Material Type (Compulsory)

The material type code(s) which further describe the physical form of the waste. Select all that apply within a specific physical form that best describe the waste material. A maximum of three (3) entries are allowed. At least one entry must be specified.

\author{
Phrsical Form: SOLD \\ MTOOI - ABSORBANT \\ MTOO2 - BIOLOGICAL \\ MTOOS - CLOTH \\ MTOOA - EQUIPMENT \\ MTOOS - GLASS \\ MTOOS - GRANULAR \\ MTOO7 - METALLIC \\ MTOOS - PAPER \\ MTOOS - PPE \\ MTO1O - PLASTIC \\ MTO11 - RUBBLE \\ MTOL2 - SOlL \\ MTO13 - WOOD \\ MTO99 - OTHER
}

\author{
Physical Form: LIOUID \\ MT200 - GROUNDWATER \\ MT201 - OLLBASED \\ MT2O2 - SOLVENT, HALOGENATED \\ MT203 - SOLVENT,NON-HALOGENATED \\ MT2O4 - WATERBASED \\ MT2O5 - WASTEWATER \\ MT206 - WELLWATER \\ MT299 - OTHER \\ Pbrsical Form: SLUDGE \\ MT400 - BIOLOGICAL \\ MT401 - OILBASED \\ MT402 - METALLIC \\ MT403 - SOIL \\ MT404 - WATERBASED \\ MT499 - OTHER
}




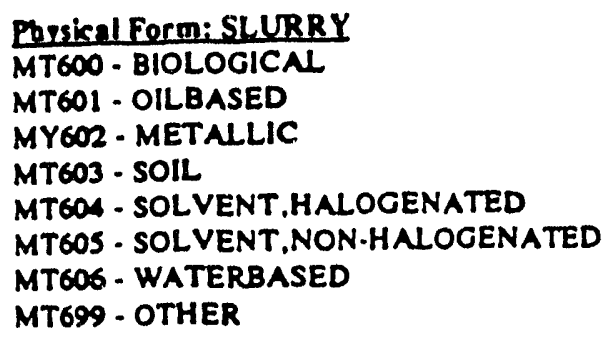

\section{Phrsical Form: EMTLSION}

MT800 - OILBASED

MT801 - WATERBASED

MTP99 - OTHER

W6. AWA No. (Compulsory)

The Asbestos Work Authorization Number.

Format: number

W7. Waste Description (Compulsory)

A general deseription of the waste material and its packaging.

Examples: Oily rags in plastic bags; Excess chemical in one liter botule

W8. Waste Calegory (Compulsory)

Specific categories for the waste material. All calegories must be checked either YES or NO to complele the form. If a particular calegory is questionable, refer to the waste acceplance criteria of the destination facility and/or site waste management procedures.

CHEMICAL

Does the waste contain polentially hazardous chemicals? If YES, complete the CHEMICAL WASTE section.

\section{RADIOACTIVE}

Does the waste contain radioactive isotopes? If YES, complete the RADIOACTIVE WASTE section.

ASBESTOS

Does the waste conlain asbestos?

SANIND

Is the waste suitable for sanitary/industrial land fill disposal?

CONST. DEBRIS

Is the waste 'clean' construction debris?

MEDICAL

Did the waste originate in a medical facility as a result of medical procedures and/or research.

BIOLOGICAL

Is the waste of biological origin (animal carcasses, landscaping refuse, ac.)?

ACCOUNTABLE

Does the waste contain accountable radioactive materials? If YES, complete the UCN 2681 No. feld (R3) with the number of the ORNL Nuclear Malerial Intra-Leboratory Transfer form (UCN-2681).

\section{CARCINOGEN}

Does the waste contain known carcinogens?

COMPACTIBLE

is the waste compactible?

REYCYCLABLE

Is the waste potentially recyclable?

\section{CLASSIFIED}

Is the waste classified material? NOTE: Classified waste cannot be disposed of at ORNL. 


\section{CHEATCAL HASTE}

M1. RCRA? (Required if Chemical waste)

Does the waste contain RCRA regulated material (40 CFR 261)?

If yes, complete RCRA 90-Day Sur Dale (M2) when applicable.

M2. RCRA 90-Day Start Dale (Conditional)

RCRA 90 The date when hazardous or mixed waste begins to accumulate in a 90 -day accumulation area. This field should NOT be conipletsis with the date waste is moved 10 a satellite accumulation area

Example: 4/1/93

M3. PCB? (Required if Chemical viaste)

Is the waste PCB (greater than 2 PPM) regulated (yes or no)?

If yes, complete PCB Start Date (M4) and PCB Concentration (MS).

M4. PCB Sun Dale (Required if PCB waste)

The dale the PCB contaminated waste item was removed fomm service or declared waste.

M5. PCB Concentration (PPM) (Required if PCB waste)

The PCB concentration in parts per million (fi less than "nnn", enter "nnn").

NOTE: Do not use less than or greater than values. Enter the number that best chancterizes your waste.

M6. Determiration Method (Required if Chemical waste)

Select from the three methods the one which was used to determine the chemical characteristics of the waste.

Note: The chemical and $m$. Ological characteristics can be determined by independent methods.

PROCESS KNOWLEDGE - Documented knowledge of the generation process parameters.

ANALYSIS - Laboratory analysis of samples of this waste item.

REFERENCE - Reference to other laboratory anslysis of similar waste (periodic sampling of a repetitive waste stram andor batch sampling analysis).

M7. Determination Document Numbers (Required if Chemical waste)

The ID numbers of documents (lab repons, MSDS sheets, process analysis reports, facility permits, ac.) which substantiate the determination of the waste characteristics. A maximum of three (3) may be specified.

Examples: MSDS8030, OAL1234

M8. Flash Point (Conditional)

The Dash point of the waste material in degrees $C$ when applicable.

Formal: number

M9. pH (Conditiona)

The relative acidity of the waste material $(\mathrm{pH})$ when applicable.

Format: number

M10. EPA Naste Code Numbers (Required if RCRA waste)

The EPA waste code numbers determined from the waste characteristics (RCRA waste only). A maximutrit of twelve (12) may be specified.

Examples: D001, U123

M11. Substance ID (Required if RCRA waste)

The ID numbers of the chemic I constituents which sigrificantly affect the characterization, handling and management of the waste. For a pure chemical, enter its Chemical Abstract Service (CAS) number. For a commercial mixture, enter its MSDS record number.

Format: 999999.99 .9 (CASM or 999999 (MSDSN

NOTE: If additional space is needed use the Waste ltem Continuation (WIC) sheed (TX-5746A), and enter a statement noting a WC sheet is auached [e.e. "WIC (TX-5745A) atusched."].

M12. Vol \% (Required if RCRA waste)

The percent by volume of the sut stance in the waste.

Format: number 
M13. Substance Name (Required if RCRA waste)

The cominon name of the chemical constituent of commercial mixture.

Examples: Ethanol, Formaldehyde, Exxon 123 Solvent

NOTE: Do nol use chernical formulas or symbols.

\section{RADIOACTIVE WASTE}

R1. Rad Calegory (Required if Radionctive waste)

Seloct one radioactive waste category code from: a) TRU (Transuranic), b) High-Level, c) Low-level, d) Special (Special Case Waste), or e) VLA Nery Low Activity).

Refer 10 the waste aceptance criteria of the destination facility and/or site waste management procedures for detailed information regarding radiosctive waste categories.

R2. Rad Handling Type (Required if Radioactive waste)

The redioactive waste handling code.

Values:

CONTACT - Conisct handled ( $5200 \mathrm{mrem} / \mathrm{hr}$ )

REMOTE - Remolely handled ( $>200 \mathrm{mrem} / \mathrm{hr}$ )

R3. UCN 2681 Number (Conditional)

The ID number of the ORNL Nuclear Material Intra-Lsboratory Transfer Form (UCN-2681) form associated with this waste item. Used for Accountable Nuclear materials only.

R4. Determination Method (Required if Radioactive waste)

Selea from the three methods the one which was used to delermine the modiological characteristics of the waste.

Nole: The chemical and radiological characteristics can be determined by independent methods.

PROCESS KNOWLEDGE - Documented knowledge of the generation process parameters.

ANALYSIS - Laboratory analysis of samples of this waste item.

REFERENCE - Reference to other laboratory analysis of similas waste (periodic sampling of a repetivive waste stream and/or batch sampling analysis).

R5. Determination Document Numbers (Required if Radioactive waste)

The ID numbers of documents (hat reports, MSDS sheets, process analysis reports, facility permits, etc.) which substantinte the determination of the waste chancteristics. A maximum of throe (3) may be specified.

Example: ORNLTM-11652, LLL1234

R6. Chemical Form (Conditional)

The chemical form of the radianctive waste item.

Specify the ONE which best describes the waste material. This is a partial listing only. If additional chemical forms are needed contact your Waste Marasement Organization representalive.

BICARBONATE
BISULFATE
BISULFTTE
BROMATE
BROMIDE
CARBONATE
CHLORATE
CHLORIDE
CHLORTE
CHROMATE

DICHROMATE
DIOXIDE
DISULFIDE
ELEMENTAL
FLUORIDE
HYDRIDE
HYDROXIDE
NITRATE
NITRIDE
NITRTTE

OXIDE

PERCHLORATE

PHOSPHATE

SULFATE

SULFIDE

SULFTTE

TETRAOXIDE

TRIOXIDE

R7. lsolope D (Required is Radioactive waste)

The $D$ of the radioisotopes contained in this waste item.

Example: PU-239, U-235, AG-110M (Refer wo Appendix A)

NOTE: If additional space is needed use the Wasw llem Continuation (WIC) shoat (TX-5746A), and enter a statement noting a WIC sheet is atuched (C.8. "WIC (TX-5745A) atuached."]. 
R8. Est. Quantity (Required if Radionaive waste)

The estimated quantity of the radioisolope in the waste. Nole the correspunding UNITS of the quantity (curies or grams) for each isolope. Specify the quantily as a decimal number or in engineering nolation. Refer to the ISOTOPE or the UNTTS field help for additional information.

Examples: .0001, .3E-3

R9. Quan. Units (Required if Radioactive waste)

The units for the radioisolope quantity.

Values: $\mathrm{G}$ (grams) or Cl (curies) (Refer to Appendix A)

\section{HANDLING INFORMATION}

H1. Handling Instructions (Optional)

General handling instructions for the waste.

Examples: See Energy Systems MSDS for instructions; Face shield required

H2. Respirator (Optional)

Respirator requirements for handling the waste. This is not completad for ORNL Generators.

Values: NONE, HALF, FULL

H3. Cartridge (Optional)

The respirator csrtridge type to be used (if applicable). This is not completed for ORNL Generators.

H4. HP Survey Daka (completed by Health Physics Lechnician)

HP Tag Color:

Surface Contamination:

The color code of the survey ug (G: UCN14B,Y: UCN2785)

Dose Rate at Surface:

The count rate from a surface swipe $(\mathrm{dpm} / 100 \mathrm{~cm} 2)$

Dost Rate at 1 Meter:

The fixed contamination dose rate measured at the surface (mrem/hr)

Instrument ID:

The dose rate measured at 1 meter $(\mathrm{mrem} / \mathrm{hr})$

The health physics instrument ID number.

Format: $A 99999$

HS. Pickup Site (Compulsory)

The site (plant) where the waste is to be picked up.

Examples: $X 10, Y 12, K_{2} S$

HJ. Pickup Facility (Compulsory)

The facility (building) where the waste is to be picked up.

Example: 4500N

H7. Pickup Room/ Area (Compulsory)

The room number or area identifier where the waste is to be picked up:

Example: 12SL

\section{SIGNATURES And APPROVALS}

S1. Generator

The signature, date and badge number of the waste generator, certifying that the information on the form is complete and accurate and that the waste is in compliance with the Waste Acceptance Criteria for the treatment, storage or disposal facility to which it is being submitted.

S2. H.P. Technician

The signature, date and badge number of the H.P. Technician certifying that the HP survey information is complete and accurate. 
53. Verification Officer

The signature, date and badge number of the Generator Cerification Official who certifiea that the waste was packaged in accondance with the TSD Facility Waste Acoppence Criteria by individusts with the appropriste training.

54. Derivative Classifier

The signalure, date and badge number of the Derivative Classifier. This signature is not required at ORNL. 


\section{APPENDIXA}

\section{RADIOISOTOPES}

The following is a list of the valid isotopes. The units of measurement (euries or grams) of the estimated guantity are also provided. When the units of measurement are dependent upon whecher the concentration of the isotope is less than or equal to $100 \mathrm{nCi} / \mathrm{g}$ or greater than $100 \mathrm{nCi} / \mathrm{g}$ it is 30 noted.

\begin{tabular}{|c|c|}
\hline Isotore & Yinits \\
\hline AC-225 & Cl \\
\hline AC-227 & Cl \\
\hline AC.228 & Cl \\
\hline AG-108 & $\mathbf{C l}$ \\
\hline AG-108M & Cl \\
\hline AG.109M & Cl \\
\hline$A G-110$ & CI \\
\hline$A G-110 M$ & Cl \\
\hline AG-111 & Cl \\
\hline AG-IIIM & CI \\
\hline NL-26 & CI \\
\hline AL-26M & Cl \\
\hline AM-239 & Cl \\
\hline AM-240 & $\mathbf{C l}$ \\
\hline$A M-241$ & $\mathrm{G}$ if $\langle=100 \mathrm{oCi} / \mathrm{g}$ else Cl \\
\hline AM-242 & cl \\
\hline NM-242M & $\mathrm{G}$ if $<=100^{\circ} \mathrm{Ci} / 8$ ele $\mathrm{Cl}$ \\
\hline AM-243 & cl \\
\hline AM-244 & Cl \\
\hline AM-24MM & CI \\
\hline AM-24S & CI \\
\hline$A M-246$ & Cl \\
\hline$A M-246 M$ & CI \\
\hline AR-39 & CI \\
\hline AS-74 & Cl \\
\hline AS-76 & Cl \\
\hline AU-195 & Cl \\
\hline AU-195M & Cl \\
\hline AU-198 & Cl \\
\hline AU-198M & Cl \\
\hline BA-131 & CI \\
\hline BA-131M & Cl \\
\hline BA-133 & Cl \\
\hline BA-133M & Cl \\
\hline $\mathrm{BA}+13 \mathrm{MM}$ & CI \\
\hline BA-129 & Cl \\
\hline BA-140 & Cl \\
\hline BE-10 & CI \\
\hline BE-7 & CI \\
\hline B1-207 & Cl \\
\hline B1-208 & CI \\
\hline BI-210 & Cl \\
\hline B1-210M & Cl \\
\hline Bl-21I & Cl \\
\hline $\mathrm{BI}-212$ & cl \\
\hline $\mathrm{BI}-212 \mathrm{M}$ & CI \\
\hline B1-213 & Cl \\
\hline B1-214 & $\mathrm{Cl}$ \\
\hline BK-219 & Cl \\
\hline$R-82$ & Cl \\
\hline$B R-82 M$ & $\mathrm{Cl}$ \\
\hline C-14 & CI \\
\hline
\end{tabular}

\begin{tabular}{|c|c|}
\hline Isolope & C'niks \\
\hline$C A-11$ & CI \\
\hline $\mathrm{CA} A \mathrm{~S}$ & Cl \\
\hline CD-104 & Cl \\
\hline CD-109 & cl \\
\hline$C D-113$ & cI \\
\hline$C D-113 M$ & Cl \\
\hline CD-11S & Cl \\
\hline CD-IISM & cl \\
\hline CE-13i & Cl \\
\hline CE-13IM & Cl \\
\hline CE-139 & ct \\
\hline CE-139M & CI \\
\hline CE.141 & Cl \\
\hline CE-142 & Cl \\
\hline CE-143 & Cl \\
\hline CE-144 & CI \\
\hline CF.249 & $\mathrm{G}$ if $\angle=100 \mathrm{aCi} / \mathrm{g}$ else $\mathrm{Cl}$ \\
\hline CF-250 & Cl \\
\hline CF-25! & $\mathrm{G}$ if $\langle=100 \times \mathrm{Ci} / \mathrm{g}$ elee $\mathrm{Cl}$ \\
\hline CF-252 & Cl \\
\hline CL-36 & $c t$ \\
\hline CM-242 & ct \\
\hline CM-243 & $G$ if $\left\langle=100 \mathrm{nCV}_{\mathrm{g}}\right.$ eles $\mathrm{Cl}$ \\
\hline CM-24 & $\mathrm{G}$ if $<=100 \mathrm{xCV} g$ elec $\mathrm{Cl}$ \\
\hline CM-245 & $\mathrm{G}$ if $\angle=100 \mathrm{nCV} \mathrm{B}_{\mathrm{B}}$ elec $\mathrm{Cl}$ \\
\hline CM-246 & cl \\
\hline CM-247 & $G$ if $<=100 \mathrm{nCi} / g$ else Cl \\
\hline CM-248 & cl \\
\hline $\cos 56$ & Cl \\
\hline ca.s7 & Cl \\
\hline ca-s8 & Cl \\
\hline $\cos 58$ & Cl \\
\hline $\cos 60$ & cl \\
\hline CO-60M & cl \\
\hline CR-SI & Cl \\
\hline $\operatorname{cs}-134$ & CI \\
\hline CS-134M & Cl \\
\hline CS-135 & CI \\
\hline CS-13SM & Cl \\
\hline CS-136 & Cl \\
\hline CS.136M & Cl \\
\hline CS.137 & Cl \\
\hline CS. 138 & Cl \\
\hline CS.138M & $\mathbf{c l}$ \\
\hline $\operatorname{cs}-139$ & $\mathrm{Cl}$ \\
\hline CU.64 & Cl \\
\hline$C U-67$ & $\mathrm{Cl}$ \\
\hline DY-166 & CI \\
\hline ES-253 & Cl \\
\hline ES.2S4 & CI \\
\hline ES.2S4M & Cl \\
\hline EU.150 & Cl \\
\hline EU-15OM & Cl \\
\hline
\end{tabular}




\begin{tabular}{|c|c|}
\hline Isologe & Luits \\
\hline EU-152 & CI \\
\hline EU-1S2M & $\mathrm{Cl}$ \\
\hline EU-154 & Cl \\
\hline EU-154M & CI \\
\hline EU.15s & CI \\
\hline EU-1S6 & $\mathrm{Cl}$ \\
\hline EU. 160 & CI \\
\hline FE-SS & CI \\
\hline FE-59 & Cl \\
\hline FM-25S & Cl \\
\hline FR-221 & Cl \\
\hline FR-223 & Cl \\
\hline GA-67 & Cl \\
\hline GA-68 & Cl \\
\hline GD-152 & Cl \\
\hline GD-153 & $\mathrm{Cl}$ \\
\hline GE-67 & Cl \\
\hline GE-68 & Cl \\
\hline $\mathrm{H}-3$ & Cl \\
\hline HF-175 & Cl \\
\hline HF-181 & Cl \\
\hline HG-197 & CI \\
\hline HG- $197 \mathrm{M}$ & $\mathrm{Cl}$ \\
\hline HG-203 & CI \\
\hline $1-123$ & CI \\
\hline $1-125$ & CI \\
\hline $1-126$ & Cl \\
\hline $1-129$ & Cl \\
\hline $\mid-131$ & Cl \\
\hline $1-132$ & Cl \\
\hline I-132M & Cl \\
\hline I-133 & Cl \\
\hline $1-133 M$ & Cl \\
\hline $1-134$ & Cl \\
\hline $1-134 M$ & Cl \\
\hline $1-135$ & Cl \\
\hline DN-111 & Cl \\
\hline $\mathrm{D}-111 \mathrm{M}$ & Cl \\
\hline$D N-113 M$ & Cl \\
\hline DN-114 & Cl \\
\hline DN-114M & Cl \\
\hline DN-115 & Cl \\
\hline DN-115M & Cl \\
\hline IR-190 & CI \\
\hline R-190M & Cl \\
\hline IR-192 & Cl \\
\hline R-192M & Cl \\
\hline IR-194 & Cl \\
\hline R-194M & Cl \\
\hline$k-40$ & Cl \\
\hline$k-12$ & CI \\
\hline K-13 & CI \\
\hline KR-81 & Cl \\
\hline KR-81M & Cl \\
\hline KR-85 & Cl \\
\hline KR-8SM & ct \\
\hline LA-138 & CI \\
\hline LA-140 & Cl \\
\hline LU-172 & Cl \\
\hline LU-172M & Cl \\
\hline LU. 17 & $\mathrm{Cl}$ \\
\hline LU-177M & CI \\
\hline MN-S2 & Cl \\
\hline MN-52M & CI \\
\hline MN-S4 & $\mathrm{Cl}$ \\
\hline imiv-56 & $\mathrm{Ci}$ \\
\hline MO99 & Cl \\
\hline NA-22 & Cl \\
\hline NA-24 & Cl \\
\hline
\end{tabular}

\begin{tabular}{|c|c|}
\hline lsotope & Lnit: \\
\hline NA.2S & CI \\
\hline NB-92 & Cl \\
\hline NB-92M & Cl \\
\hline NB-93M & Cl \\
\hline NB-94 & $\mathrm{Cl}$ \\
\hline NB.94M & $\mathrm{Cl}$ \\
\hline NB-95 & $\mathrm{Cl}$ \\
\hline NB-9SM & $\mathrm{Cl}$ \\
\hline ND-144 & $\mathrm{Cl}$ \\
\hline ND-147 & $\mathrm{Cl}$ \\
\hline ND-149 & $\mathrm{Cl}$ \\
\hline NT-56 & $\mathrm{Cl}$ \\
\hline Nl.59 & $\mathrm{Cl}$ \\
\hline$N ! 63$ & $\mathrm{Cl}$ \\
\hline NP-233 & $\begin{array}{l}\mathrm{Cl} \\
\mathrm{Cl}\end{array}$ \\
\hline NP.233 & $\begin{array}{l}\mathrm{Cl} \\
\mathrm{G} \text { if }<=100 \mathrm{DCV} \mathrm{V}_{\mathrm{g}} \text { ele Cl}\end{array}$ \\
\hline $\begin{array}{l}\text { NP.236 } \\
\text { NP.236M }\end{array}$ & $\begin{array}{l}G \text { if }<=100 \mathrm{DCi} / \mathrm{glse} \mathrm{Cl} \\
\mathrm{Cl}\end{array}$ \\
\hline NP-237 & $\mathrm{G}$ if $<=10 \mathrm{nCi} / \mathrm{g}$ else $\mathrm{Cl}$ \\
\hline NP.238 & CI \\
\hline NP.239 & Cl \\
\hline NP-240 & Cl \\
\hline NP-240M & $\mathrm{Cl}$ \\
\hline NP.241 & $\mathrm{Cl}$ \\
\hline OS-185 & $\mathrm{Cl}$ \\
\hline OS-190M & $\mathrm{Cl}$ \\
\hline OS-191 & $\mathrm{Cl}$ \\
\hline OS-191M & $\begin{array}{ll}\mathrm{Cl} \\
\mathrm{Cl}\end{array}$ \\
\hline OS-193 & $\begin{array}{l}\text { Cl } \\
\text { Cl }\end{array}$ \\
\hline $\begin{array}{l}\text { OS-194 } \\
\text { P-32 }\end{array}$ & $\begin{array}{l}\mathrm{Cl} \\
\mathrm{Cl}\end{array}$ \\
\hline P-33 & $\mathbf{C l}$ \\
\hline PA-230 & $\mathrm{Cl}$ \\
\hline PA-231 & Cl \\
\hline PA.232 & Cl \\
\hline PA.233 & $\mathrm{Cl}$ \\
\hline PA.234 & Cl \\
\hline PA-234M & CI \\
\hline PA-235 & $\mathrm{Cl}$ \\
\hline PB-196 & $\begin{array}{l}\text { Cl } \\
\text { Cl }\end{array}$ \\
\hline PB-203 & $\begin{array}{l}\text { Cl } \\
\text { Cl }\end{array}$ \\
\hline PB-203M & $\begin{array}{l}\text { Cl } \\
\text { Cl }\end{array}$ \\
\hline $\begin{array}{l}\text { PB-204M } \\
\text { PB-205 }\end{array}$ & $\begin{array}{l}\text { Cl } \\
\text { Cl }\end{array}$ \\
\hline PB-209 & $\mathbf{C l}$ \\
\hline PB-210 & Cl \\
\hline PB-211 & $\mathbf{C l}$ \\
\hline PB-212 & $\mathrm{Cl}$ \\
\hline PB-214 & Cl \\
\hline PD-103 & $\mathrm{Cl}$ \\
\hline PD-107 & $\mathrm{Cl}$ \\
\hline PD-107M & Cl \\
\hline PD-109 & $\begin{array}{l}\mathrm{Cl} \\
\mathrm{Cl}\end{array}$ \\
\hline PD-109M & $\begin{array}{l}\mathbf{C l} \\
\mathbf{C l}\end{array}$ \\
\hline PM-146 & $\begin{array}{l}\text { Cl } \\
\text { Cl }\end{array}$ \\
\hline $\begin{array}{l}\text { PM-147 } \\
\text { PM-148 }\end{array}$ & $\begin{array}{ll}\text { Cl } \\
\text { Cl }\end{array}$ \\
\hline$P M-148 M$ & $\mathrm{Cl}$ \\
\hline$P M-149$ & $\mathrm{Cl}$ \\
\hline$P O-210$ & Cl \\
\hline PQ-211M & $\mathrm{Cl}$ \\
\hline$P O-212 M$ & $\mathrm{Cl}$ \\
\hline PO-218 & $\mathrm{Cl}$ \\
\hline PR-142 & $\mathrm{Cl}$ \\
\hline PR-142M & $\mathrm{Cl}$ \\
\hline PR-143 & Cl \\
\hline $\begin{array}{l}P R-144 \\
P R-14 M\end{array}$ & $\begin{array}{l}\mathrm{Cl} \\
\mathrm{Cl}\end{array}$ \\
\hline $\begin{array}{l}\text { PR-14MM } \\
\text { PT-185 }\end{array}$ & $\begin{array}{l}\text { Cl } \\
\text { Cl }\end{array}$ \\
\hline
\end{tabular}



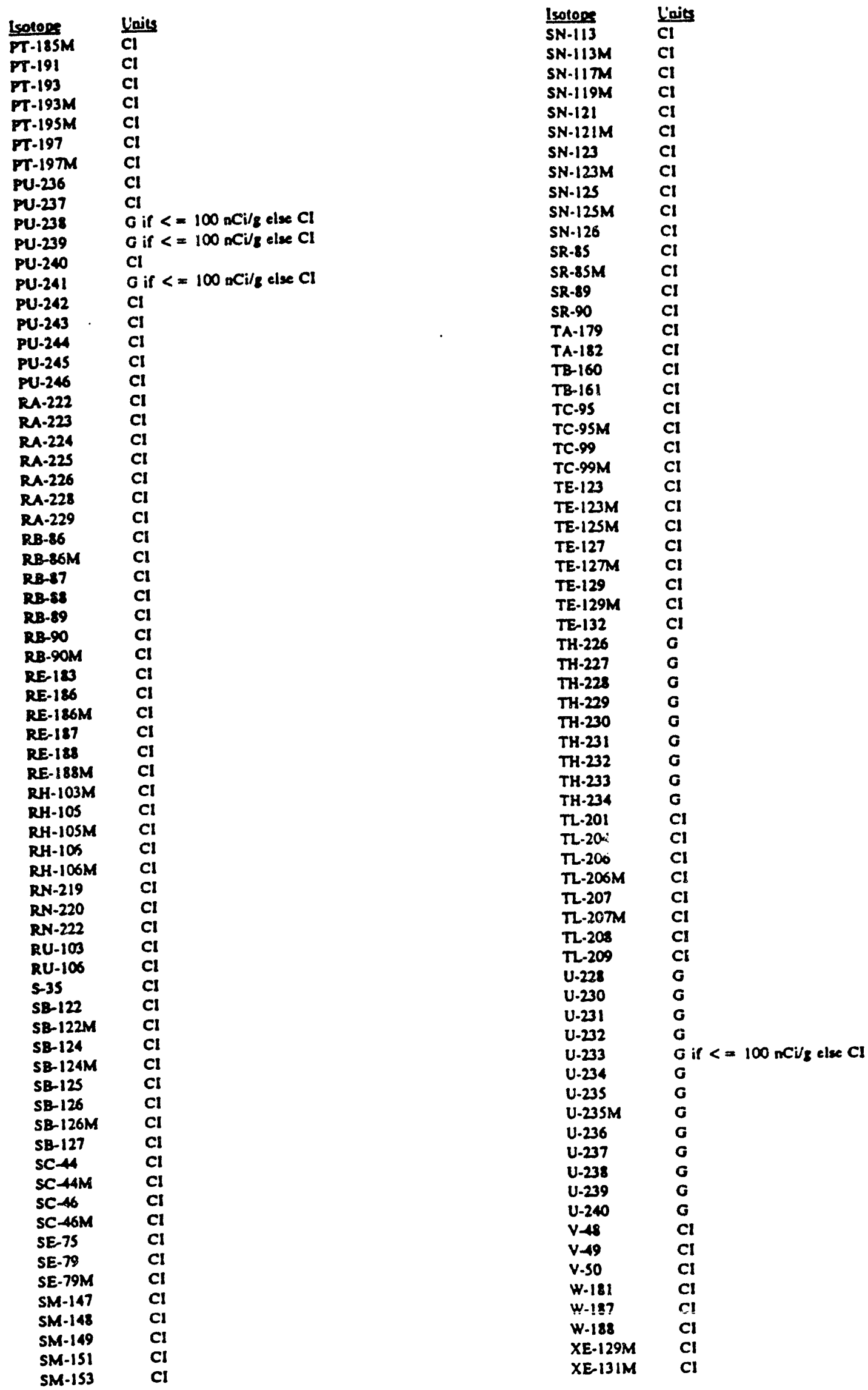

July 12, 1993 


\begin{tabular}{|c|c|}
\hline Isolor & Yoiss \\
\hline$\overline{X E-133}$ & $\mathrm{Cl}$ \\
\hline XE.133M & $\mathrm{Cl}$ \\
\hline Y-88 & $\mathrm{Cl}$ \\
\hline$Y-90$ & $\mathrm{Cl}$ \\
\hline Y.90M & Cl \\
\hline$Y-91$ & $\mathrm{Cl}$ \\
\hline$Y-91 M$ & CI \\
\hline YB-169 & $\mathrm{Cl}$ \\
\hline YB-169M & Cl \\
\hline YB-175 & $\mathrm{Cl}$ \\
\hline $2 N-63$ & Cl \\
\hline $2 N-65$ & $\mathrm{Cl}$ \\
\hline ZR.93 & Cl \\
\hline ZR-95 & Cl \\
\hline
\end{tabular}




\section{MARTIN MARIETTA}

\section{CONTAINER PACKING LIST}

\section{CONTADER DENTIFICATION}

C1. Conlainer ID. No.

C2. Coulainer Type

C3. Holding Site
C4. IIolding Facility

CS. Holding Room/Are

\section{CONTAINER PACKING LIST}

\begin{tabular}{|c|c|c|c|}
\hline I1. Waste Item ID Number & I1. Waste Item ID Number & I1. Waste Item ID Number & I1. Waste Item ID Number \\
\hline & & & \\
\hline & & & \\
\hline & & & \\
\hline & & & \\
\hline & & & \\
\hline & & & \\
\hline & & & \\
\hline & & & \\
\hline & & & \\
\hline & & & \\
\hline & & & \\
\hline & & & \\
\hline & & & \\
\hline & & & \\
\hline & & & \\
\hline & & & \\
\hline & & & \\
\hline & & & \\
\hline & & & \\
\hline & & & \\
\hline & & & \\
\hline & & & \\
\hline & & & \\
\hline & & & \\
\hline & & & \\
\hline & & & \\
\hline & & & \\
\hline & & & \\
\hline
\end{tabular}

HANDLDG DNFORMATION

\begin{tabular}{|c|c|c|c|c|c|c|c|c|c|}
\hline \multirow{2}{*}{\multicolumn{4}{|c|}{ H1. Handling lustructions }} & \multirow{2}{*}{$\begin{array}{l}\text { IIf. H/l Tag } \\
\text { Color }\end{array}$} & \multicolumn{2}{|c|}{ 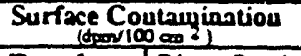 } & \multirow{2}{*}{$\begin{array}{l}\text { Dose Rate } \\
\text { at Surface } \\
\text { (oromere }\end{array}$} & \multirow{2}{*}{$\begin{array}{c}\text { Dase Rate } \\
\text { at } 1 \text { Meter } \\
\text { (1) }\end{array}$} & \multirow{2}{*}{$\begin{array}{l}\text { Instrument } \\
\text { Ideatification }\end{array}$} \\
\hline & & & & & Transfer. & Direct Read. & & & \\
\hline & & & & Alphs & & & & & \\
\hline H2. Respirator & & & \multirow[t]{2}{*}{ H3. Cartridge Type } & Bets/Gamme & & & & & \\
\hline ]None [ & Half & $\square$ Full & & Neutron & & $\therefore$ & & & \\
\hline
\end{tabular}

SIGNATURES and APPKO V̈ȦLS S1. Certification Onicer

S. WMO

\begin{tabular}{|l}
\hline Badge \\
\hline Badge
\end{tabular}

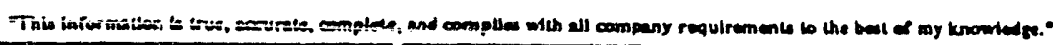

St.

\section{Badge \\ Badge}

Date

Date 


\section{Container Packing List (TX-5749) Form User Instructions}

PURPOSE; The Container Incking List (CPL) form is used to describe a single standard shipping/storage container which holds multiple, separately identified waste items. This type of packing is often referred to as 'lab-packing'. It differs from a 'bulking operation' in that the waste items, once packed, retain their original identities and characteristics. The CPL lists the type and identity of the standard shipping/storage container, the identities of all of the waste items packed inside it, and any applicable handling information.

Multiple, separately identified waste items which are being lab-packed in the field often originate from several different waste generators and locations within the generating organization. A Generator Cerification Officer is responsible for ensuring that each waste items packed in the container is identified with a properiy completed WDD and attached barcode label, verifying that the container is properiy sealed and labeled, and that the waste package meets all applicable site criteria for transfer to the site waste management organization.

\section{CONTAINER IDENTIFICATION}

C1. Container ID No. (Compulsory)

The unique ID number of the standard shipping/storage container for this waste item copied from the container barcode label. If the waste is placed in a non-standard container (glass botule, vial, bag, etc.) or is self-contained enter 'NA'.

Example: X10C9300123

C2. Conksiner Type (Compulsory)

The container type code of the outer container of the waste item. If the container type is not a listed 'standard container' (large, well-defined containers), use the most detailed 'generie' container type available. If there is no suitable container type code or the waste item is self contained, enter 'SELF' and provide any additional packaging information in the WASTE DESCRIPTION.

Examples: DRUMS55, DRUMS30 (Refer to WD instructions item C2.)

c3. Holding Site (Compulsory)

The site (plant) where the waste item/contsiner was held during waste accumulation. If the waste was not held in a location during accumulation different from the generation location enter 'NA' and omit Holding Facility (C4) and Holding Room Area (CS)

Examples: X10, Y12, K2S

C4. Holding Facility (Compulsory)

The facility (building) where the waste container was held during waste accumulation.

Example: $4500 \mathrm{~N}$

C5. Holding Room/Area (Compulsory)

The room/area identifier where the waste container was held during waste accumulation.

Example: 125L

\section{CONTAINER PACKING LIST}

11. Waste Irem ID Number (Compulsory)

The unique ID number of each waste item in the conlainer from the barcode labels attached to the waste items.

Example: X1019300001

\section{HANDLING INFORMATION}

H1. Handling Instructions (Optional)

General handling instructions for the waste.

Examples: See MSDS for instructions; Face shield required

H2. Respirator

Respirator requirements for handling the waste. This is not completed for ORNL generators.

Values: NONE, HALF, FULL

H3. Cartridge 
The respirator cantidge type to be used (if applicabie). This is not completed for ORNL generators.

H4. HP Survey Data (completed by Health Physics t schnician) (Compulsory)

HP Tag Color:

The color code of the survey ug (G: UCN14B, Y: UCN2785)

Surface Contamination:

The count rate from a surface swipe $(\mathrm{dpm} / 100 \mathrm{~cm} 2)$

Dose Rate at Surface:

The fixed contamination dose rate measured at the surface $(\mathrm{mrem} / \mathrm{hr})$

Dose Rate al 1 Meter:

The dose rate measured at 1 meter $(\mathrm{mrem} / \mathrm{hr})$

Instrument ID:

The health physics instrument ID number.

Format: A99999

\section{SIGNATURES and APPROVALS}

S1. Certification Officer (Compulsory)

The signature, date and badge number of the Generator Certification Officer, certifying that the information on the CPL is complete and accurate, that the waste package complies with waste acceptance criteria of the treatment, storage or disposal facility to wisch it is being submited and that the waste was packaged by individuals with appropriate training.

S2. H.P. Technician (Compulsory)

The signature and badge number of the H.P. Technician certifying that the HP survey information is complete and accurate.

53. Verification Officer

The signature and badge number of the Waste Management Organization (WMO) representative verifying that the CPL and all associated WID forms have been completed properly. 


\section{MARTIN MARUETTA}

\section{WASTE PICKUP REQUEST}

REQUEST IDENTIFICATION

PI. Request Niumber

PS. Request Date

P10. Comwents

\section{PICKUP LIST}

L1. Waste Item or Container ID
P2. Requestor's Naule (priut)

P6. Pickup Site
P7. Picliup Facility
P3. Badge No.

P8. Pickup Room/Area
P4. Requestor's Phode No.

$\mid \begin{array}{r}\text { P9. Urgency } \\ \square \text { Roultine } \square \text { Urgent } \\ \square \text { Critical }\end{array}$

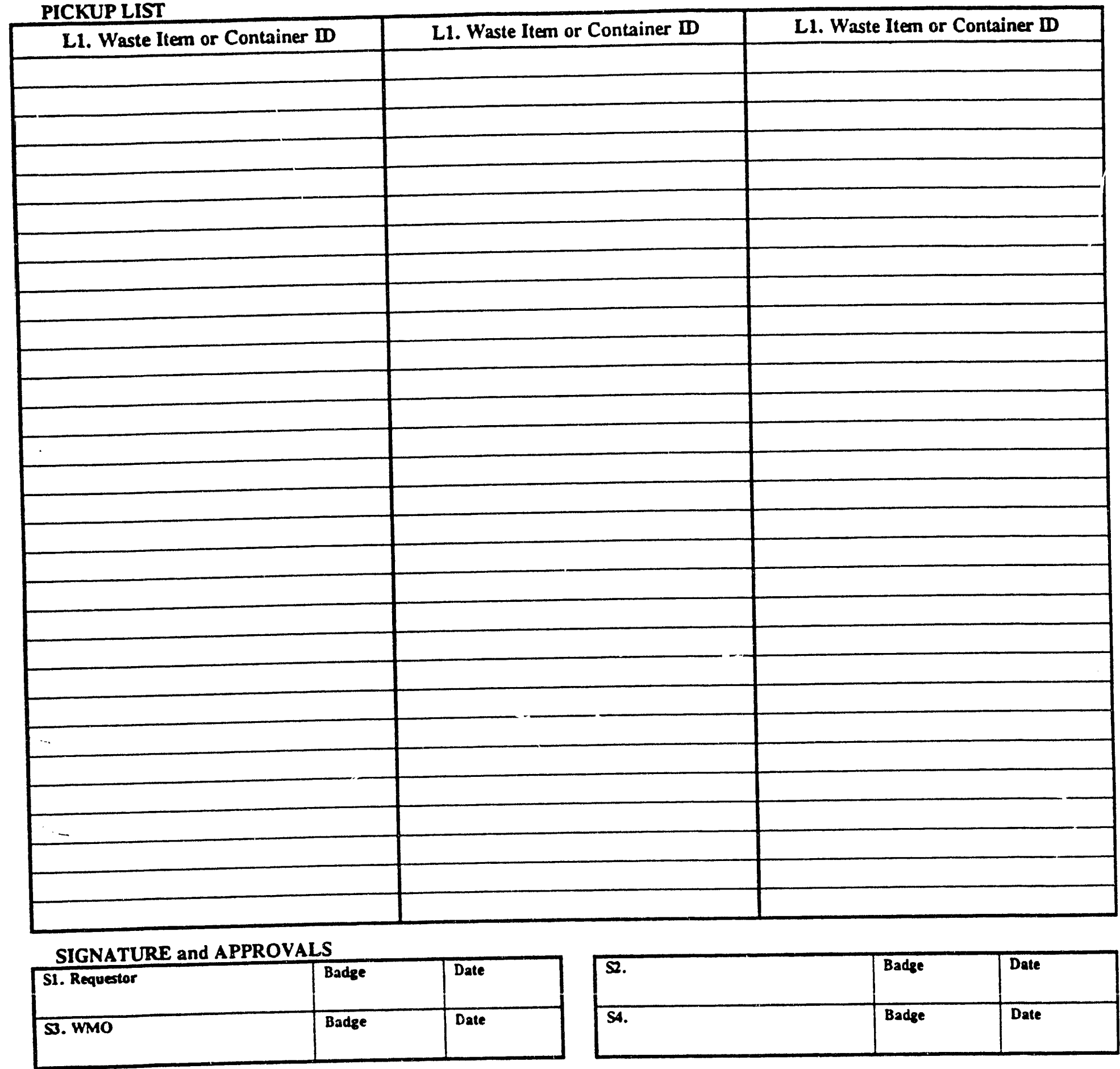




\section{Waste Pickup Request (TX-5753) Form User Instructions}

PURPOSE: The Waste Pickup Request (WPR) form is used to request the pickup of waste. It lists the identities of self-eonlained waste items and/or standard waste shipping/storage containers to be picked up for treatment, storage or disposal. The WPR is submitted to the site waste management organization along with the corresponding set of Waste liem Description (WID). Waste Item/Container List (WICL), and Container Packing List (CPL) forms. The WPR is uniquely identified by a request ID barcode placed on the form.

Any proper combination of WID. WICL and CPL forms is acceptable for use with the WPR, however all waste items/containers must be at the same pickup location.

\section{REOUEST IDENTIFICATION}

Barcode Label (upper right comer):

Each WPR request document is uniquely identified by abaching a pre-printed request ID barcode label in the rectangular box located in the upper right comer of the form.

P1. Request ID Number (Compulsory)

Copy the unique ID number of the WPR document from the barcode label attached to the form.

Example: "X10R9300123"

P2. Requestor's Name (Compulsory)

PRINT the name of the individual responsible submitting this waste pickup request.

P3. Requestor's Badge No. (Compulsory)

The badge number of the requestor.

Example: 99999

P'4. Requestor's Phone No. (Compulsory)

The phone number where the requestor can be reached.

Example: (615) 576-99999

P5. Request Date (Compulsory)

The date that the waste pickup request was completed.

Example: 4/1/93

P6. Pickup Site (Compulsory)

The site (plant) where the waste is to be picked up.

Examples: X10, Y12, K2S

P7. Pickup Facility (Compulsory)

The facility (building) where the waste is to be picked up.

Example: $4500 \mathrm{~N}$

P8. Pickup Room/Area (Compulsery)

The room or area where the waste is to be picked up.

Example: $125 \mathrm{~L}$

P9. Urgency (Compulsory)

The urgency with which this request should be handled. Provide justification for Urgent and Critical in the Comment section (P10).

Values:

ROUTINE - Process request normally

URGENT - Need pickup soon

CRITICAL - Need pickup immediately; regulatory or saftey violation possible

P10. Comments (Optional)

Any additional information affecting this waste pickup request.

\section{WASTE ITEM OR CONTARINER ID}


L1. Contsiner ID Number (Compulsory)

Copy the unique ID number of each wast: item or container to be picked up from the corresponding barcode labels.

Examples: "X10C9300123" (container) or "X101900001" (waste item)

\section{SIGNATURES and APPROVALS}

\section{S1. Requestor}

The signature, date and badge number of the person submitting the waste pickup request certifying that all associated WID. and CPL forms are ansched.

S3. Verification

The signature, date and badge number of the Waste Management Organization (WMO) representative certifying that the WPR and all associated forms have been completed properly. 


\section{DISTRIBUTION}

1. J. K. Bailey

2. L. D. Bates

3. C. A. Bednarz

4. D. T. Bell

5. S. C. Bieniek

6. T. M. Bonine

7. H. L. Boston

8. S. N. Burman

9. T. W. Burwinkle

10. P. J. Campbell

11. R. T. Carvin

12-16. C. Clark

17. A L. Cook

18. K. W. Cook

19. R. B. Cook

20. N. S. Dailey

21. M. F. P. DeLozier

22. D. B. Elkins

23. S. B. Garland II

24. C. D. Goins

25. J. A. Greene

26. K. G. Greer

27. J. T. Grumski

28. P. J. Halsey

29. R. A Harris

30. V. Holt

31. L. D. Hyde

32. R. J. Hydzik, Jr.

33. E. J. Jackson

34. L. L. Kaiser

35. C. M. Kendrick

36. B. L. Kimmei
37. A. J. Kuhaida, Jr.

38. S. L. Laman

39. J. R. Lawson

40. L. W. Little

41. R. C. Mason

42-44. D. M. Matteo

45. B. C. McClelland

46. J. D. Miller

47. R. L. Mlekodaj

48. T. J. Newsom

49. C. E Nix

50-51. P. T. Owen

52. R. A. Peters

53. J. S. Phillips

54. T. F. Scanlan

55. P. A. Schrandt

56. C. A. Schrof

57. J. A. Setaro

58. C. M. Smith

59. B. P. Spalding

60. J. Stellern

61. M. W. Tull

62. S. D. Van Hoesen

63. R. K. White

64. M. L. Whitehead

65. A. S. Will III

66. P. S. Wood

67. Central Research Library

68-72. ER Document Management Center

73-74. Laboratory Records Dept.

75. ORNL Patent Section

76. Office of Assistant Manager for Energy Research and Development, DOE Oak Ridge Operations Office, P.O. Box 2001, Oak Ridge, TN 37831-8600

77. A. Brill, Ogden Environmental and Energy Services Company, 800 Oak Ridge Turnpike, Oak Ridge, TN 37830

78. P. Chatterji, EBASCO Services, 111 Union Valley Road, Oak Ridge, TN 37831

79. C. M. Davis, Bechtel National, Inc., P.O. Box 350, Oak Ridge Corporate Center, 151 LaFayette Drive, Oak Ridge, TN 37830

80. F. F. Haywood, Radian Corporation, 120 S. Jefferson Circle, Oak Ridge, TN 37830

81. J. Holden, Bechtel National, Inc., P.O. Box 350, Oak Ridge Corporate Center, 151 Lafayette Drive, Oak Ridge, TN 37830

82. J. R. Kannard, Program Manager, Bechtel National, Inc., P.O. Box 350, Oak Ridge Corporate Center, 151 LaFayette Drive, Oak Ridge, TN 37830

83-84. J. T. Sweeney, DOE Oak Ridge Operations Office, P.O. Box 2001, Oak Ridge, TN 37831-8541

85. D. W. Swindle, Radian Corporation, 120 South Jefferson Circle, Oak Ridge, TN 37830 
86. T. J. Wheeler, Radian Corporation, 120 S. Jefferson Circle, Oak Ridge, TN 37830

87-88. Office of Scientific and Technical Information, P.O. Box 62, Oak Ridge, TN 37831 

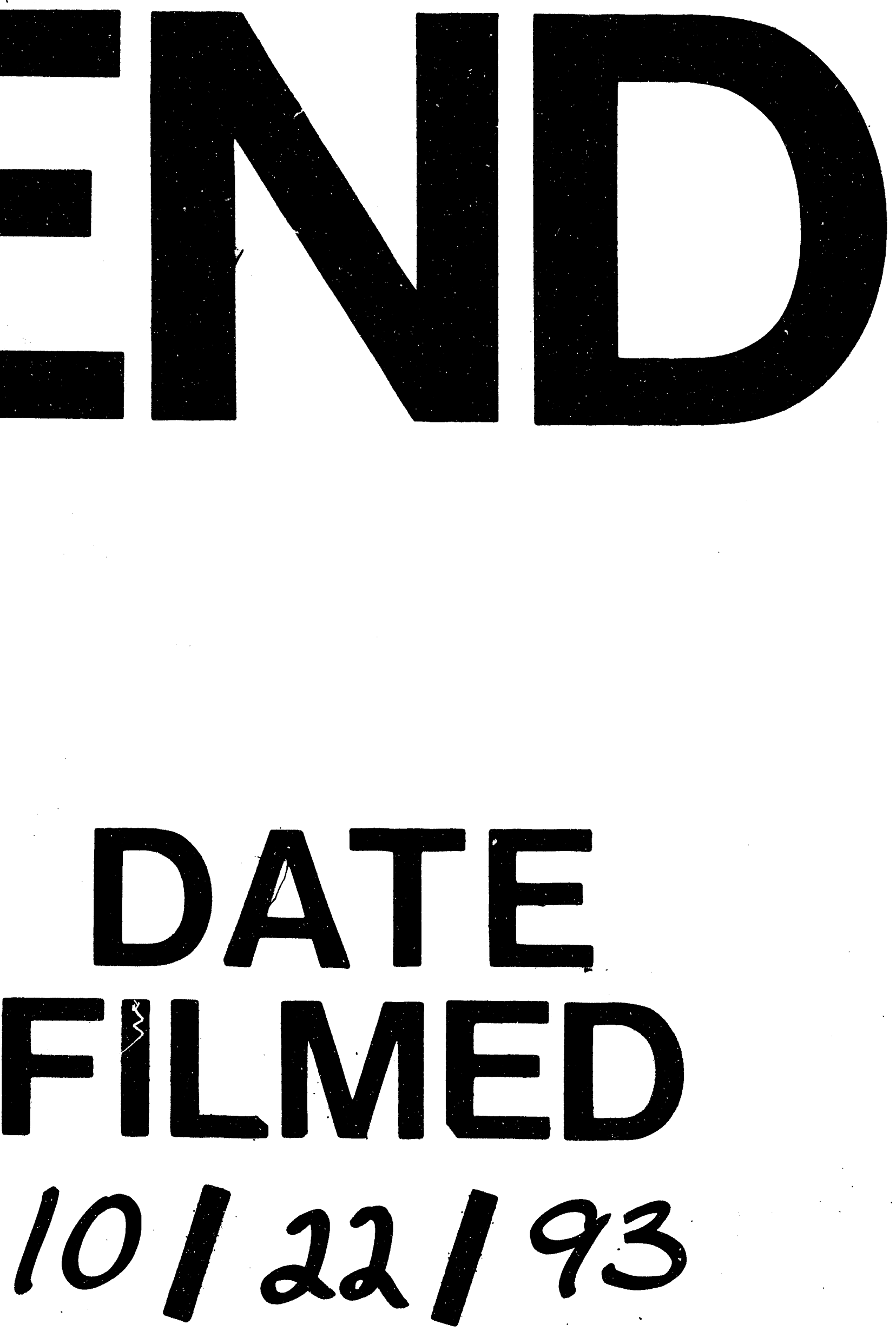
